
Dur Mra. Josiah C.Richarden

With love and all highregard. from Rear. 


\section{Digitized by the Internet Archive in 2007 with funding from Microsoft Corporation}

http://www.archive.org/details/helpstoreadingofo0richiala 


\title{
HELPS TO THE READING OF CLASSICAL LATIN POETRY
}

\author{
BY \\ LEON JOSIAH RICHARDSON
}

Cantantes licet usque - minus via laedit - eamus

GINN \& COMPANY

BOSTON - NEW YORK - CHICAGO - LONDON 
Copyright, 1907, BY LEON JOSIAH RICHARDSON

ALL RIGHTS RESERVED

77.1

Ebe atbenaum Bress 
And when we have learned by long familiarity to read between the lines, to apportion the emphasis, to reproduce, it may be, in imagination some shadow of that "marvelous witchery" with which, as tradition tells us, Vergil's own reading of his poems brought out their beauty, we shall be surprised at the amount of self-revelation discernible beneath the calm of his impersonal song.

F. W. H. Myers. 



\section{PREFACE}

That the vox viva has a vital part to play in the study of language, seems to call for little argument. The one is closely bound up in the other. In numberless ways sound is accommodated to sense; and this holds true alike of ancient and modern tongues. Moreover, the literatures of the Greeks and Romans have always been regarded as preëminently human, hence called the "humanities," which accords with the fact that they are permeated with ideas not merely well suited to rocal expression, but frequently such as can be fully conveyed only by means of the living voice. In discussing the style of poets, Cicero went so far as to say "Nonnulli eorum voluptati vocibus magis quam rebus inserviunt" (Orator, $\mathrm{xx}, 68$ ).

The following pages concern the student of the Roman poets, especially Vergil and Ovid. They aim to promote modes of study that shall react farorably upon the mother tongue, that shall yield good training, reasonable command of the Latin language, and some well-founded conceptions of antiquity. They aim to make it clear that reading (as opposed to the "puzzling out" method of study) furnishes at all stages the true key to sense, and that without such reading one will fail to enter into the full comprehension, as well as the highest enjoyment, of the poetry. The principles gorerning Latin metrical composition in the Augustan age will be briefly set forth. For a full 
treatment of the subject the student should consult such authorities as Sievers, Corssen, Lindsay, Christ, and Gleditsch. A further comparison between classical and English versification may be found in the works of Mayor, Omond, and Saintsbury.

Some of the illustrative material used in this book has been drawn from W. Christ, Die Metrik fer Griechen und Römer; H. W. Johnston, Metrical Licenss of Vergil; the Allen and Greenough, Hale and Buck; Gildersleeve and Lodge, and Lane Latin grammars; the Century and Standard dictionaries; and an article by the author "On the Form of Horace's Lesser Asclepiads," American Journal of Philology, xxii, 283. The words Vergil, rime, and meter, when spelled otherwise in quoted passages, have been brought into line with the usage followed in this book.

For aid and suggestion acknowledgment is made to Professor Isaac Flagg, Professor William A. Merrill, Professor Edward B. Clapp, and Professor Henry W. Prescott. Special thanks are due the Reader of Messrs. Ginn and Company, whose coöperation has added much to whatever merit this little volume may possess.

L. J. R.

University of CALifornia

Berkelex, December, 1906 


\section{CONTENTS}

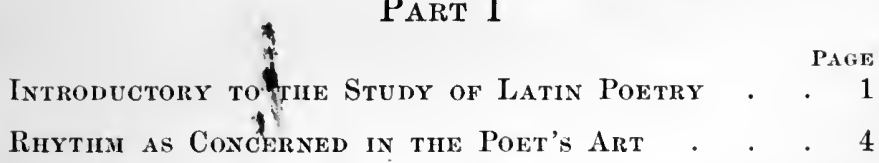

The Nature of Rhythm . . . . . . . 4

The Interlacing Series in a Poetic Rhythm . . . 7

Rhythm and Meter . . . . . . . . 8

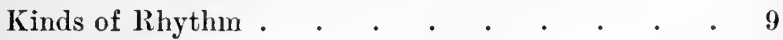

Auxiliary Factors . . . . . . . . . 10

Relation of Rhythm to Ideas . . . . . . $\quad$. 19

Direct and Indirect Ways of Conveying Thought $\quad 19$

Rhythm an Example of the Latter . . . . . 19

Rirtimical Elements . • • • • . • • . 22

Syllables . . . . . . . . . . . 22

Feet . . . . . . . . . . . . 44

Cola . . . . . . . . . . . . . 46

Verses . . . . . . . . . . . . 47

Groups of Verses . . . . . . . . . 50

\section{PART II}

The Dactylic Hexameter and Pextaneter • • . 51

Practical Hints on Readixg Latin Poetry • • . 62

INDEX . 



\section{THE READING OF CLASSICAL LATIN POETRY}

\section{Part I. General Principles}

\section{IN'TRODUCTORY TO THE STUDY OF LATIN POETRY}

Almost every thing we do in our daily lives involves ways and methods that are not original but come to us as the accumulated result of a long line of human experience. And so to understand fully any activity one must view it historically, one must follow it through the various stages of its development. Speaking, reading, and writing are no exceptions to this rule. And since the three enter so largely into the discipline of the mind, the questions are coustantly arising: What literatures should we study? How can the ancient classics be treated to the best advantage ?

In taking up Greek or Latin, young people are set to learning forms, parsing, translating, and the like. Such exercises have their place, and indeed are important, provided they be looked upon as a means to an end. Too often, however, they are allowed to become ends in themselves, with the result that the student does not learn to read in the true sense of the term. In this field, as elsewhere, a great deal depends upon beginning rightly. 
The Latin student, already grounded in simple prose and now aplroaching the poets, should hear Latin poetry read in large masses by a reader competent to give fair enunciation and expression; and then, while the sounds are still ringing in his ears, he should read for himself. The more he reads aloud the better. In the early stages of practice he can not be expeeted to understand at once all he hears, nor to know much about the structure of the verse. The main thing at this period is to form right habits, especially the habit of gathering the sense from the page in a normal way - not by rearranging the words, but by taking them into the mind through the genuine process of "straight-ahead" reading. If he perseveres in hearing, reading aloud, and - we may add - writing, he will soon begin to take a Roman's attitude toward the literature; more and more he will read with ease and pleasure, and finally the poetry will reveal its true meaning and beauty.

Professor Shorey's remark on the part played by the voice in the study of Horace's Odes may be applied widely:

Wsthetic criticism of Horace's exquisite metrical art ean be addressed only to those who read him alond precisely as they read English poetry. Such students will observe for themselves in their favorite passages the reënforcement of the leading thoughit by the emphasis of the rhythm, the symmetrieal responsions and nice interlockings of words and phrases, the dainty but not obtrusive alliteration, the real or faneied adaptation of sound to sense in softly musical, splendidly sonorous, or picturesquely descriptive lines. This kind of criticism may easily pass into the fantastic. It is better suited to the living roice than to cold print. 
To read Latin poetry in this spirit is not a simple matter. Not only must one make the words embody the properties that would belong to them in prose - correct syllabic form, quality and quantity of sound, accent, intonation, and logical grouping - but one must also utter the words with a feeling for the rhythmical series which they are intended to suggest, and here and there with regard to still subtler effects of sound. For the complete impression that the poet seeks to convey results from an interplay among all these elements.

If it is worth while to study ancient literature at all, it is certainly worth while to enter as fully as possible into its spirit, to lay hold on its store of thought and feeling. Niebuhr puts the matter well in his Letter to a Young Philologist :

Do not read [ancient authors] in order to make æsthetic reflections upon them, but in order to drink in their spirit, and to fill your sonl with their thoughts - in order to gain by the reading what you would have gained by reverently listening to the discourses of great men. This is the philology that does the soul good; and learned investigations, even when we get so far as to be able to make them, always occupy an inferior place. Even if we can explain the most difficult passages at sight, all this is nothing, and mere sleight of hand, if we do not acquire the wisdom and spiritual energy of the great men of antiquity, - think and feel like them.

\section{Professor Corson says: ${ }^{1}$}

A true poem is a piece of articulate music which may require to be long practiced upon by the roice before all its possible significance and effectireness be realized.... Reading must supply all the deficiencies of written or printed language. It must

1 The Voice and Spiritual Education, pages 29 and 63. 
give life to the letter. IIow comparatively little is addressed to the eye, in print or manuscript, of what has to be addressed to the ear by a reader! There are no indications of tone, quality of voice, inflection, pitch, time, or any other of the vocal functions demanded for a full intellectual and spiritual interpretation. A poem is not truly a poem until it is voiced by an accomplished reader who has adequately assimilated it - in whom it has, to some extent, been born again, according to his individual spiritual constitution and experiences.

In short, one must first understand in order to read well. And so it comes about that the most satisfactory test of a person's mastery over a piece of literature, whether poetry or prose, is his ability to read it aloud.

\section{RHYTHM AS CONCERNED IN THE POET'S ART}

\section{The Nature of Rhythi}

What is the nature of rhythm as an element in poetry? $I_{1}$ seeking to answer this question one should bear in mind that poetic rhythm is only a specialized form of sometling that may be met with on every hand. In its widest sense - that is, as conditioned by "periodicity, rise and fall, recurrence of maxima and minima" rhythm is an inseparable property of motion. And so, whether we regard a storm, the flight of a bird, or everyday speech, rhythm is never absent. This wide application of the word is in keeping with its derivation from pv$\theta \mu o^{\prime}$, whose meaning is measured motion and whose root signifies flow. Rhythm is instinctive in man and a necessary part of his nature. It pervades all his actions, especially those involving emotion. Curiously enough 
rhythm has an important effect on memory. That is to say, one is more likely to remember an utterance that is rhythmical than one that is unrhythmical. It therefore comes about through no mere chance that proverbs and other sayings handed down from age to age are almost invariably cast in a highly rhythmical form. Hence, too, the antiquity of poetry; its rhythmical character rendered transmission by memory possible before the invention of writing.

In the course of time man has developed certain modes of activity called the arts, three of which are based on rhythm: namely, dance, music, and poetry. Here only such rhythm is admitted as appeals readily to the human mind and serves to rouse or satisfy emotion.

Our knowledge of rhythm as thus employed is derived in no small degree from the Greeks. Plato considered it to be measured motion ( $\dot{\eta} \tau \hat{\eta} \varsigma \kappa \iota \nu \eta^{\prime} \sigma \epsilon \omega \varsigma \tau a^{\prime} \xi \iota s$. Leges, $665 \mathrm{~A})$. Aristotle held that all rhythm is measured by motion which has certain defined limits $(\pi \hat{a} s \dot{\rho} v \theta \mu \grave{s} s \hat{\omega} \rho-$

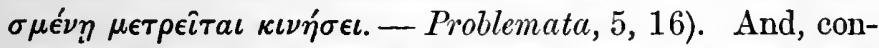
sistently with this view, Aristoxenos regarded rhythm as divisions of time marked off from one another and drawn

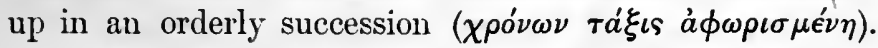
James Hadley, in his essay on rhythm and meter, amplifying the thought of Aristoxenos, defines rhythm as "a regular succession of times ... so marked off and distinguished that the proportionality of the times and the regularity of their succession shall be obvious to human sense. These times may be marked by the movements of the body, as in dancing; by tones of various pitch and stress, as in music; by syllables of uttered words, as in poetry.... 
These principles do not require words for their manifestation; they do not require even sounds; the silent art of orchestic has its arses and theses, its trochees and iambuses, its dactyls and anapests, not less truly than music and poetry."

In line with the same ancient authority is the definition of Professor Milton W. Humphreys: "Rhythm is the division of time into small, approximately equal units by corresponding units of sound, or less sensibly by muscular movement or visible motion. Rhythm bears the same relation to time that symmetry does to space. The arts of space and rest - statuary, architecture, and painting are based on symmetry, while the arts of time and motion - dance, music, and poetry - are based on rhythm."

By way of further illustration, suppose that there be produced an indefinite series of perfectly monotonous sounds, such as come from a metronome, - each sound separated from the next by a constant interval, each identical with every other in duration, intensity, and quality. To the mind hearing these sounds and itself supplying nothing - if this were possible - there would be no rhythm in the artistic sense of the term; there would be nothing to determine how many sounds constituted a group, or how long the divisions were. But on the other hand, should, say, every second sound be made to differ in some particular from the rest, whether in duration, intensity, pitch, or adjacent interval, there would then spring into being rhythm of the general type employed in art. ${ }^{1}$

1 " The phenomena proper to rhythm are identical in music and verse. The characteristic differences between the two lie solely in the nature of their secondary factors. The rhythms of music are 


\section{The Interlacing Series in a Poetic Rhythm}

When a poem is read or sung we come under the sway of rhythm that results not from a single series of time divisions but from several such series running simultaneously and harmoniously ; some divisions are shorter, some longer; those of a given series have approximately equal duration. In the following example from Burns we may regard the several series one at a time.

a. Ye banks | and braes | o' bon | ie Doon, | How can | ye bloom | sae fresh | and fair! | Iow can | ye chant, | ye lit | tle birds, | And I / sae wea | ry, fu' | o'care!

b. Ye banks and braes | o' bonie Doon, | How can ye bloom | sae fresh and fair!| How can ye chant, | ye little birds, | And I sae wea | ry, fu' o' care!

c. Ye banks and braes o' bonie Doon, | How can ye bloom sae fresh and fair!| How can ye chant, ye little birds, | And I sae weary, fu' o' care!

d. Ye banks and braes o' bonie Doon, How can ye bloom sae fresh and fair! | How can ye chant, ye little birds, And I sae weary, fu' o' care!

So harmoniously are the different series interrelated that the hearer feels them all at the same time and as one rhythm, the smaller amplitudes reënforcing the larger

expressed in forms which have rich and pleasing qualities-tones; those of verse are supported by forms which arouse varied and beantiful images - articulate speech. In the former the immediate sensuous quality of the sound predominates, the ideas suggested are secondary, obscure, or lacking; in the latter the images which the words call to mind absorb attention, while the musical qualities of the voice are usually meager or unheeded. It is, therefore, a natural result that in music the formal conditions of rhythm are faithfully observed, while in verse they are transgressed constantly and with freedom." - Professor Robert MacDougall, Psych. Review, January, 1903. 
ones. Thus the complexity of rhythm in this comparatively simple song becomes apparent. The poet has had the skill, if we may use a musical figure, to set his language simultaneously to several series of different periods or amplitudes.

\section{Rhythm and Meter}

We hear the expressions "the rhythm of a poem" and "the meter of a poem." What then is the distinction between rhythm and meter? Rhythm is a widely inclusive term, as appears in the foregoing discussion. Meter, however, is limited to the field of language (and music), where it denotes rhythm, not in all its rich detail, but to the extent of its main plan, - namely, those rhythmic relations that conform to a system of fixed measures. This measuring process is practicable only when the divisions recur regularly and the included sounds are arranged according to some pattern or definite plan, as is the case in poetry. The description of specimen series, therefore, gives one an idea of the rhythm throughout a whole composition. In prose, while there is rhythm, the divisions are too variable, both in duration and structure, to be treated in this manner: hence the canon that prose should embody a certain rhythm or harmonious movement, but one not so precise as to give the effect of meter. Rhythm in one form or another belongs to prose and poetry, meter to poetry alone.

The distinction between these terms is further illustrated in the following remarks of C. S. Calverley (Works, page 498 ff.) :

What appears to me to be the almost universal fallacy of metrical writers is the assumption that when you have got the 
scansion of a line you have got its rhythm.... Meter... is, in my riew, a sort of framework whose office is to support the rerse. It is possible to train a rose or a vine npon a trellis so that, while it adheres firmly, it is still left to follow its own derices and form its own pattern over the laths, which are only seen here and there amongst the leaves and tendrils. It would also be possible to force every branch and spray into strict conformity with the lines of the frame, so that the outline of its squares should be the only outline visible. The former method seems to me to be the way in which Homer and Vergil, and all poets ancient or modern, .... have dealt with ineter.

In other words, meter is not synonymous with poetic rhythm in its whole ${ }^{1}$ range, but rather with the ground form of such rhythm. Meter connotes less than rhythm. The former relates simply to scansion, that is, to the form of a poem as measured by feet, cola, verses, and the like. The latter relates to all factors, even the most subtle and indirect, that produce the flow of sound as organized by the poet.

\section{Kixps of Rhythy}

It is customary to divide poetic rhythms into classes on the basis of the constituent elements of the time divisions. These divisions in the case of English or German poetry are occupied by syllables whose most notable sound characteristic is that some are more heavily stressed than others. More or less similar is the poetry of many other modern languages. The rhythm, therefore, in these cases belongs to the accentual class, because it is marked to a greater or less extent by accent or stress. On the other

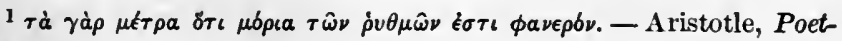
ics, 4,6 . 
hand, the divisions of Greek or Latin poetry are occupied by syllables whose most notable sound characteristic is that some last a longer time than others. In this case the rhythm belongs to the quantitative class. Cf. ictus, p. 44 .

Whether accentual or quantitative, the rhythm of poetry is reënforced by certain special effects; that is to say, certain turns of sound or periods of silence are introduced in such a manner and at such points as to signalize the rhythmical divisions. These auxiliary factors, as they may be termed, are not all present in every language, nor is it the poet's way to employ many simultaneously. As division succeeds division they are sometimes numerous, sometimes few. Those most commonly employed are as follows :

1. Silence. One can not properly read a poem, or sing a song, without observing certain moments of silence, rhythmical conditions requiring $(a)$ rests and $(b)$ pauses, sense conditions requiring $(c)$ stops.

a. Not infrequently it serves the poet's purpose to leave a brief portion of the rhythm unoccupied by sound. The resulting silence is termed a rest. This has three characteristics: it occurs within rhythmical divisions (feet); its duration is prescribed by the form of these divisions; its bearing on the rhythm is direct. The first line of the following selection contains a rest in each foot.

$$
\text { On thy } \mid \begin{aligned}
& \text { Break, } \text { cold gray } \mid \text { break, | stones, } 0 \mid \text { break, } \\
& \text { Sea ! }
\end{aligned}
$$

The movement of these verses has been well represented in musical symbols by. Mr. William Thomson, The Basis of English Rhythm, page 54. 
$b$. The rhythm of a poem is here and there momentarily suspended, giving place to a pause. This has three characteristics: it falls sometimes within, sometimes between, rhythmical divisions; its duration is not definitely fixed by these divisions, being left to the interpretation of the individual reader or singer; its bearing on the rhythm is indirect. Examples of pauses are indicated by perpendicular lines in verses $b, c$, and $d$ on page 7 .

c. Speech naturally falls into phrases, clauses, and sentences, - in short, into divisions commonly set off from one another by stops. Their location is shown on the printed page for the most part by punctuation. In poetry, no less than in prose, stops are needed to make the language clear and easily intelligible. They help the meaning without doing violence to the rhythm, just as rests and pauses help the rhythm without doing violence to the meaning. Rests and pauses, being governed by rhythmical laws, recur with much regularity; stops, on the other hand, being governed by rhetorical laws, respond to the widely varying demands of thought. Accordingly, a sense division now coincides, now falls at variance, with a rhythmical division, each gaining something from the other, each being in a degree restrained by the other. This illustrates well how the poet's 'art maintains a nice balance between content and form.

If the sense divisions of a poem repeatedly coincide with the rhythmical divisions, the effect in reading is a kind of "sing-song." Mother Goose abounds in examples:

Sing a song of sixpence,

A pocket full of rye ;

Four and twenty blackbirds

Baked in a pie. 
When the pie was opened, The birds began to sing; Was not that a dainty dish To set before the king?

The king was in his counting-house,

Counting out his money; The queen was in the parlor, Eating bread and honey ;

The maid was in the garden, Hanging out the clothes; When up came a blackbird, And nipped off her nose.

Opposed to this style of composition is the complex form, one wherein the rhythmical divisions do not predominantly correspond with the sense divisions. A good example of this is found in Tennyson's In Memoriam. The poet makes the two correspond often enough to keep the reader conscious of the type of the rhythm; but non-correspondence is also present to satisfy the subtle laws of variety and beauty. The following selection may serve as an example:

What hope is here for modern rhyme

To him, who turns a musing eye

On songs, and deeds, and lives, that lie

Foreshorten'd in the tract of time?

These mortal lullabies of pain

May bind a book, may line a box,

May serve to curl a maiden's locks;

Or when a thousand moons shall wane

A man upon a stall may find, And, passing, turn the page that tells

A grief, then changed to something else, Sung by a long-forgotten mind. 
But what of that? My darken'd ways Shall ring with music all the same; To breathe my loss is more than fame, To utter love more sweet than praise.

2. Sound Parallelism. Under this head are included rime, assonance, and alliteration. These effects are so arranged by the poet that, among other things, they may help define for the hearer the rhythmical divisions. For example, without the aid of rime one would hardly obtain a true impression of the rhythm of a sonnet, whose verses often close without sense pauses. The hearer could not always be sure where the verses end, and the musical effects would be obscured.

Like rime in its relation to rhythm is assonance, with its correspondence of vowels but not of consonants, as in: the following example:

Maiden, crowned with glossy blackness,

Lithe as panther forest-roaming,

Long-armed naiad, when she dances,

On a stream of ether floating.

George Eliot, The Spanish Gypsy.

The part played by assonance in the evolution of poetic forms has been happily touched upon by Walter Pater in his remarks on the old French songs contained in the thirteenth-century romance Aucassin et Nicolette:

The songs themselves are of the simplest kind, not rimed even, but only imperfectly assonant, stanzas of twenty or thirty lines apiece, all ending with a similar vowel sound. And here, as elsewhere in that early poetry, much of the interest lies in the spectacle of the formation of a new artistic sense. A new music is arising, the music of rimed poetry, and in the songs of Aucassiu 
and Nicolette, which seem always on the point of passing into true rime, but which halt somehow, and can never quite take flight, you see people just growing aware of the elements of a new music in their possession, and anticipating how pleasant such music might become. - The Renaissance, page 18 .

Alliteration was used regularly in old Teutonic poetry as a means for pointing the rhythm.

Hire robe was ful riche of red scarlet engreyned.

Piers Plowman, ii, 15.

It occurs to some extent in all poetry, and almost never without some bearing on rhythm. Here are some examples:

Some lump, ah God, of lapis lazuli,

$B$ ig as a Jew's head cut off at the nape,

$B l u e$ as a vein o'er the Madonna's breast.

Browning, The Bishop Orders his Tomb.

Would that the structure brave, the manifold music I build,

Bidding my organ obey, calling its keys to their work,

Claiming each slave of the sound, at a touch, as when Solomon willed

Armies of angels that soar, legions of demons that lurk, Man, brute, reptile, fly, - alien of end and of aim,

Adverse, each from the other heaven-high, hell-deep removed, -

Should rush into sight at once as he named the ineffable Name,

And pile him a palace straight, to pleasure the princess he loved !

Would it might tarry like his, the beautiful building of mine,

This which my keys in a crowd pressed and importuned to raise!

$\mathrm{Ah}$, one and all, how they helped, would dispart now and now combine,

Zealous to hasten the work, heighten their master his praise ! 
And one would bury his brow with a blind plunge down to hell,

Burrow awhile and build, broad on the roots of things, Then up again swim into sight, having based me my palace well, Founded it, fearless of flame, flat on the nether springs.

Browning, Abt Vogler.

It is instructive to compare the stanzas throughout the whole of this poem and to note that alliteration is introduced not haphazardly, but in close conformity with the plan of the rhythm.

Examples in Latin poetry are often met with:

illī indīgnantēs māgnō cum murmure montis. — Verg. Aen. i, 55. solvite çorde metum Teucrī sêclūdite cūrās. —ib. i, 562 . levis crepante lympha dēsilit pede. - Hor. Ep. xvi, 48.

3. The Connected or Disconnected Character of Sounds. Syllables are ordinarily uttered either in smoothly connected successions or detached from one another. These effects are not unlike legato and staccato notes in music. The fact is, our speech has here many gradations, several of which may not infrequently be detected within the limits of a single verse, or even of a single word. The relative closeness of sounds serves different purposes, one of which is to support the rhythm, though this is done in ways that are extremely subtle and seldom consciously apprehended perse. These effects play through the succession of sounds in such a manner that, as the need arises, the rhythmical divisions are thereby emphasized and thrown into relief. The poet indicates them to some extent in his text, but a great deal has to be left to the feeling and interpretation of the individual reader or singer. For an example take Tennyson's lines :

Thou read the book, my pretty Vivien!

$O$ ay, it is but twenty pages long. 
A sort of balance or parallelism is here brought about by the alternation of staccato and legato effects (the former being indicated by dots).

4. Location of Correlated Expressions. Coördinate words or parts of words may be so placed by the poet that rhythmical divisions are thereby thrown into relief. Take, for example, these lines from Pope's Essay on Criticism, where the quotations are introduced in such a manner that they set off the limits of the verse and, less exactly, the limits of its two main divisions:

While they ring round the same unvaried chimes,

With sure returns of still expected rhymes;

Where'er you find " the cooling western breeze,"

In the next line it " whispers through the trees."

This point, however, finds happiest illustration, not in our own so-called analytic languages but rather in the synthetic languages, like Greek or Latin, where word order is not much bound by grammatical considerations, but is free for a wide range of rhetorical effects. The bearing of word order on the rhythm, as regards the Latin language, may be illustrated by the following verses from Horace's Odes :

(1) Chiasmus.

lūctantem İcariîs | fluctibus Ā fricum. - i, 1, 15.

(2) Agreement of the first and last words in a verse. Myrtōum pavidus | nauta secet mare. - i, 1, 14.

(3) Corresponding inflectional endings at the close of the halves of a rerse.

quidquid dē Libycīs | verritur āreìs. — i, 1, 10. 
(4) Interlocked word order.

Maecēnās atarīs | èdite rēgibus. - i, 1, 1.

(5) Each half of a verse occupied by a closely knit word group.

obstrictīs alīis | praeter Iāpyga. - i, 3, $\mathbf{4}$.

(6) Anaphora.

nec trīstīs Hyadas | nec rabiem Notī. - i, 3, 14.

(7) A pair of coördinate words may be placed:

$a$. As the initial words in the halves. These halves may belong to the same verse, as in 6 above, or to different verses.

$m \bar{e}$ doctārum ederae | praemia frontium

dîs miscent superis : | mé gelidum nemus. - i, 1, 29-30.

seu vīsa est catulīs | cerva fidēlibus,

seu rūpit teretēs | Marsus aper plagās. — i, 1, 27-28.

b. As the pirotal words in the halves.

spernit, nunc viridī | membra sub arbutō strātus, nunc ad aquae | lēne caput sacrae. - i, 1, 21-22.

quās aut Parrhasius | prōtulit aut Scopās. —iv, 8, 6.

After all, when one reads a poem from the printed page, the mechanical devices for producing rhythm, such as have been described, would avail little without the reader's instinct to rhythmize. The rhythm is something more than the sound materials employed in producing it. So deep is a feeling for rhythm grounded in human nature that when the reader catches the suggestion of the poem's rhythm he is somehow impelled from within to carry it forward in its ideal form, himself making good any 
shortcomings and irregularities that may be inherent in the language of the poem. ${ }^{1}$

It may be noted in this connection that sounds for any reason subject to variation in speech, when introduced into a poem, are uttered in the particular form that is suited to the place in the verse where they occur. Thus, through the constraint of rhythm, rime, or some other influence in the poet's art, $(a)$ an old-fashioned pronunciation may be demanded, as when wind reverts to wind, or charmed to charmèd; $(b)$ a sound may be somewhat curtailed or extended; as an example of the latter, country is sometimes given the value countree; $(c)$ two syllables, whether of a single word or of adjacent words, sometimes under particular circumstances are reduced to one; as when heaven is sounded heav'n, or the eternal becomes th'eternal. Once in a while the reader or singer is led to

1 "Nor . . can we refer the pleasure of rhythmical apperception or activity wholly to the sensuous feeling and organic reverberation aroused.... The pleasure derives not from the quality of the individual elements . . but evolves also from the fact that the rhythm is characterized by formal unity, that it possesses a beginning, a climax, an end, as individual and definite as the quality of the single beat or the constitution of the unit group which enters into it; and this sense of the complete formal sequence is present from the begiming and pervades the whole experience of rhythm. Curtail the series, and its fragmentariness is immediately felt as an imperfection of the rhythmic form; add redundant elements, and the overstepping of the natural rhythmic close is felt in the same immediate way; introduce incongruous forms of temporal or intensive relation, and the discrepancy jars upon the resthetic consciousness as a violation of the sequence which the rhythmical formation demands. A rhythmical series uncompleted or wrongly executed may haunt the mind for honrs or days, until satisfaction is obtained at last by striking the final note or singing the phrase in correct time." - Professor MacDongall, Psych. Review, January, 1903. 
make two syllables out of what ordiuarily strikes the ear as one; as when legion becomes legi-on. All these variations are generally introduced by the poet only when something of the kind becomes necessary to make the sounds suggest adequately the rhythmical divisions. He is not justified in any variations that are so violent as to obscure the identity of the words, nor in any without basis and warrant in the usages of speech.

\section{Relation of Rhythm to Ideas}

A word has a twofold use. On the one hand it conveys a direct literal meaning such as is ascribed to it in the dictionary. On the other hand it often indirectly suggests meaning. For example, in accordance with the principle of onomatopoia, it may call up some idea by its mere sound; again, words may have such interrelations of sound as rime, assonance, or alliteration, and thereby produce emphasis or some other effect on the mind of a hearer; again, the sound properties of a word may be so articulated with those of preceding and following words that rhythm results. In these and many other ways the sounds of words may be so arranged and managed that they suggest more than is conveyed by their direct meaning.

The way a poet makes his language indirectly suggest meaning has been happily touched upon by Mr. F. W. H. Myers in his essay on Vergil:

In poetry of the first order, almost every word (to use a mathematical metaphor) is raised to a higher power. It continues to be an articulate sound and a logical step in the argument; but it becomes also a musical sound and a center of emotional force. It becomes a musical sound; - that is to say, its consonants and 
vowels are arranged to bear a relation to the consonants and ruwels near it, - a relation of which accent, quautity, rime, assonance, and alliteration are specialized forms, bnt which may be of a character more subtle than any of these. And it becomes a center of emotional force; - that is to say, the complex associations which it evokes modify the associations eroked by other words in the same passage in a way quite distinct from grammatical or logical connection. The poet, therefore, must avoid two opposite dangers. If he thinks too exclusively of the music and the coloring of his verse - of the imaginative means of suggesting thought and feeling - what he writes will lack reality and sense. But if he cares only to communicate definite thought and feeling according to the ordinary laws of eloquent speech, his rerse is likely to be deficient in magical and suggestive power.

And what is meant by the rague praise so often bestowed on Vergil's unequaled style is practically this, that he has been, perhajs, more successful than any other poet in fusing togetler the expressed and the suggested emotion; that he has discovered the hidden music which can give to every shade of feeling its distinction, its permanence, and its charm; that his thoughts seem to come to us on the wings of melodies prepared for them from the foundation of the world.

Rhythm does not exist as a thing by itself, but is part of a larger whole. As viewed here, it is one among a number of correlated forces that make up a poem. And, what seems at first thought beyond human skill, all these forces are made to act upon a hearer through the medium of a single current of syllables. For how otherwise does a poem when read or sung strike the ear? To arrange a succession of syllables with sole reference to rhythm is perhaps not difficult; but to arrange them so that the selfsame series shall embody, in due form and as occasion demands, words, phrases, clauses, sentences, pauses, 
accent, quantity, rhythm, rime, alliteration, assonance, onomatopœia, harmony, variety, symmetry, and other poetic properties, all contributing directly or indirectly to the sense, is a rare feat of creative skill. Thought expressed in prose enters the mind of a hearer directly and through few doorways; but thought in poetic form is borne in upon the mind along more avenues of approach, each message confirming and reënforcing every other. ${ }^{1}$

A poem may be regarded as the outpouring of thought in words so chosen and ordered that, when uttered naturally, they carry with them a complex and subtle accompaniment, this in no way distracting attention but rather contributing something to the force of the thought. It is significant that the rhythmical cadences of prose are generally most marked in passages of strong emotion, as though the speaker there found the literal meaning of words insufficient and instinctively sought additional ways of driving home his thought and feeling.

1 This principle finds illustration in any poem. Especially interesting, however, in this connection is Vergil, G. i, 322-334, on which passage Papillon and Haigh have the following note: "'This description of a storm is perhaps one of the most highly worked and carefully finished passages in Vergil or any other poet - language, imagery, and rhythm all combining to produce consummate poetic effect. Note especially the force of the pauses in $324,326,329-331$, and 333 ; of the perfects fugere and stravit, 330, 331; of the expressions ruit, 324 , spirantibus, 327 , corusca, 328 ; of the alliterations in 329,330 , and of sound and rhythm alike in 334. Dr. Kennedy says on 328-334, 'The pause at dextra marks the calmness of conscious strength; at tremit, breathless terror; at pavor, prostrate expectation. The following ille and the thrice repeated aut express the majestic ease of omnipotence; at deiicit falls the sudden crash of the bolt; in the words which follow is heard the rushing, struggling, moaning tempest." ", 


\section{RHY'THMICAL ELEMENTS}

\section{SYLLABles}

Rhythm as involved in poetry has been considered in the foregoing pages along general lines, but from this point onward the subject will be restricted to the single field of Latin. It is now in order to develop somewhat more fully a phase of the subject already touched upon, namely, the part played by syllables. The existence of syllables rests upon a natural basis. The voice can not convey a succession of thoughts except by being varied into different sounds, and these can not be sufficiently numerous and distinguishable for our needs except by the introduction of such as break or hinder the current of breath, producing a division into syllables. The poet's recognition and selection of syllables for the purposes of versification, far from being a highly artificial process, is mainly subconscious. His standard and criterion are not the dictionary, nor words sounded separately, but audible, fluent speech. And so it not infrequently happens that when one word is merged into another, the result is a syllable that embraces parts of two words. To read Latin poetry well, one must bring out distinctly the sound properties of the syllables, some of these properties being inherent in the separate syllables, some resulting from the effect one syllable has upon another. What, in detail, are these properties?

A syllable comprises a vowel alone, a diphthong alone, or either in close union with one or more consonants. Latin vowels, according to the ancients, fell into three classes: (1) those of brief duration and therefore considered short, (2) those more extended in time and therefore considered 
long, and (3) those occurring in closely knit pairs, called diphthongs, the same being long. Consonants seemed to affect the length of syllables, in that syllables were spoken more or less quickly, and therefore occupied more or less time, according to the number, order, and position of the consonants.

In the daily speech of the Romans the syllables, if exactly measured, must have occupied many different lengths of time. This is borne out by analogy with other languages and by certain lines of internal evidence. For example, take the syllabic combinations of consonant and vowel sounds known to the Latin language, as shown in the following table ( $\mathrm{v}=$ short vowel; $\bar{v}=$ long vowel or diphthong; $c=$ consonant):

\begin{tabular}{|c|c|c|}
\hline \multirow{5}{*}{ Short Syllables } & & \\
\hline & & e(III) \\
\hline & $\mathrm{cv}$ & $f u(\overline{1})$ \\
\hline & $\operatorname{ccv}$ & sta(tus) \\
\hline & $\operatorname{ccc} v$ & stru(ō) \\
\hline \multirow{19}{*}{ Long Syllables } & $\overline{\mathrm{r}}$ & $\bar{o}$ \\
\hline & $c \bar{v}$ & $d \bar{a}$ \\
\hline & $\operatorname{cc} \bar{v}$ & $s t \bar{a}$ \\
\hline & $\operatorname{ccc} \bar{v}$ & strāa(tus) \\
\hline & $\mathrm{vc}$ & et \\
\hline & crc & sit \\
\hline & ccric & stat \\
\hline & eccre & stric(tus) \\
\hline & $\overline{\mathrm{v}} \mathrm{c}$ & $\overline{o s}$ \\
\hline & $c \bar{r} \mathrm{c}$ & $s \bar{s} s$ \\
\hline & cст̄c & stäs \\
\hline & $\operatorname{cec} \overline{\mathrm{v}} \mathrm{c}$ & strūc(tus) \\
\hline & $\mathrm{vec}$ & est \\
\hline & crec & sunt \\
\hline & cevec & stant \\
\hline & ecerec & strix \\
\hline & rec & (sci)ēns \\
\hline & cīcc & dâns \\
\hline & ecv̄ec & stāns \\
\hline
\end{tabular}


Manifestly the time required for uttering these diverse forms varies considerably. And yet a system of rersification that should take into account many syllabic lengths would be unwieldy. The Romans, therefore, did well to recognize two and, in the main, only two lengths of syllables in their language, namely short and long. A long syllable was normally taken to have twice the duration of a short syllable. The latter derived its length from the average duration of the most rapidly uttered syllables in easy, fluent speech. People of slow enunciation naturally protracted their syllables more than rapid speakers, but for purposes of rendering poetry whatever time was normally taken by an individual in uttering an average short syllable became for him a standard of length.

In Latin poetie rhythm the shortest durations having a clearly marked unity are the feet. A foot, however, is made up of a certain number of still shorter durations, or brief spaces of time, each made sensible to the ear by a syllable, rarely by a rest, contained within it. (For convenience, such spaces of time composing a foot will hereafter be referred to as metrical spaces, or simply spaces.) A short space (known also as a time, mora, sēmeion, or $\chi \rho o ́ v o s ~ \pi \rho \hat{\omega} \tau o s)$ is the amount of time that ean be filled out, at least approximately, by a short syllable. It is commonly represented by the symbol $\checkmark$ and by the musical sign of the eighth note $(\boldsymbol{\beta})$. Long spaces also enter into the composition of feet, less often triple spaces and quadruple spaces. A long space has twice the duration of a short one and is approximately filled by a long syllable. It is represented by the symbol - and by the musical sign of the quarter note $(\%)$. An iambic foot, for 
example, is represented metrically by $\checkmark-$ and musically by p, being composed of two spaces, a short followed by a long. These are filled, at least approximately, by a short syllable and a long syllable respectively. A triple space has thrice the time of a short one and is filled by a long syllable sustained - partly by its own usual length and partly by the regulating effect of the rhythm - throughout the prescribed space. It is represented by the symbol $\llcorner$ or $\lrcorner$ and by the musical sign of the dotted quarter note (ץ). A quadruple space, similar to the foregoing except that it is equal to the sum of four short spaces, is represented by the symbol $\sqcup$ and by the musical sign of the half note $(\rho)$. The four spaces just described are sometimes spoken of as monosemic, duosemic, trisemic, and tetrasemic respectively. If the time normally occupied by any syllable of a word in common speech should vary perceptibly from the space, whatever it may be, where the poet has placed it, the reader or singer, guided by his feeling for the swing of the rhythm as a whole, increases or diminishes the sound to fit the conditions.

A syllable is said to be closed when it ends with a consonant, and open when it ends with a vowel.

What sounds, it is now in order to ask, were acceptable to the Roman ear in short spaces, what ones in long spaces? Manifestly a short syllable was placed within a short space and a long syllable within a long space. But precisely what conditions were present in syllables that ranked as short and what in those that ranked as long? In seeking an answer to this question we should constantly regard Latin versification in the light of the conditions 
amid which it originated and developed. It is well, for example,

1. To bear in mind that this mode of versification grew up at an early period among the Greeks, and was subsequently superimposed upon Latin, which had already been fitted to a radically different system of rersification, one wherein stress elements probably played an important part.

2. To realize as fully as possible the peculiarities of Greek pronunciation, especially those affecting the quantity of syllables.

3. To realize the circumstances of poetical composition. The art of versification, being rooted in feeling, was doubtless well established before rules were drawn up, and in all periods must have been practiced to a certain extent without reference to them.

4. To know, therefore, that syllables, as rhythmical. elements, assume their real form not when spelled, but when sounded.

5. To take into account the fact that singing was the forerunner of poetry and in a sense gave rise to it, as is hinted by the double meaning of á $\epsilon i \delta \epsilon \iota \nu, c a r m e n$, and cancre. Accordingly the speech-sounds appropriate within a given metrical space were originally those which it was easy and natural to sing in that situation.

6. To note what meaning lies in the fact that a verse as it appeared on the written page was often continuous, there being no more space between words than between letters of the same word.

7. To realize that carrying out completely the laws of poetic expression presupposes a perfect poet, 
working with perfect language materials. We may not assume, therefore, that every Latin verse coming down to us from antiquity is a perfect thing; here and there one feature must have been realized somewhat at the expense of another.

Since we can no longer listen to the living voices of the Greeks and Romans, the best we can do in seeking an answer to our proposed questions is to study Greek and Latin poetry in the form in which it survives, together with recorded testimony of the ancients and analogous usages of modern speech. In the first place, it is to be observed that every syllable comprises one or more of the three following elements:

1. The ante-vowel element (often wanting).

2. The vowel element (never wanting).

3. The post-vowel element (often wanting).

In the first syllable of $\bar{e}-b u l-l i-e n-d \bar{o}$, for example, the vowel element alone is present, in the second syllable all three elements, in the third syllable the ante-vowel and the vowel elements, in the fourth syllable the vowel and postvowel elements.

We are now in a position to consider a very important point in the nature of syllables. While the component elements are generally so thoroughly welded together that they are not separately appreciated, still each element influences directly or indirectly the amount of time taken up by a syllable. The ante-rowel element, howerer, seems to have little or no effect. Practically it does not take up time. This was the feeling of the ancients, at least, and much the same thing is true of ourselves. When a syllable containing all three elements is sounded 
in our ears we do not ordinarily begin to take note of the time occupied until the rowel element sets in. The time that the syllable seems to occupy is determined mainly by the vowel and post-vowel elements. The ante-vowel element, therefore, for purposes of Latin versification does not increase the quantity of the syllable to which it belongs. In the following verse of the $\operatorname{Encid}(i, 102)$, for example,

tālia iactantī strīdēns Aquilōne procella,

the syllables $a$, ne, and pro each fill a short space. We have, therefore, as a working rule: Ante-vowel consonants with in a syllable do not affect its quantity.

A well-attested fact has been handed down to us from antiquity, namely, that a single consonant occurring between two rovels of a word is sounded more closely with the latter than with the former vowel. For example, $b e-n e-f i-c i-a$. From this it appears at once that initial and medial short syllables end with a short vowel. But when words are uttered in a smoothly connected succession, as is usually the case in Latin verse, somewhat the same principle applies to final syllables. ${ }^{1}$ That is, if a word ends with a consonant and the ultima of that word serves to fill a short metrical space, as in primus of the first example below, the rhythmical flow of the language, when sung or read, tends to carry the sound of the final consonant over to the initial vowel of the next word. Even in our heavily accented English this usage holds to sonie extent, for we say quite naturally in fluent speech a-tome instead of at home, and a-tall instead of at all. In

$1 \ldots$ in carminibus . . exigitur strūctūra quaedam et inoffēnsa cōpulātiōo vōcum. - Quintilian, i, 10, 23. 
order to illustrate and to bring this point squarely before us, take the verses :

arma virumque canō Trōiae quī prīmus ab ōrīs. - Verg. Aen. i, 1 . accēpit galeā et prīmus clāmōre secundō. — ib. v, 491.

Speech sounds, let us bear in mind, are symbolized to the eye by absolutely distinct letters, whereas in actual utterance they are fluid in character and often merge in one another. The syllables of Tröiae, for example, are conventionally represented Trō-iae. This implies a sharp division; the probability is, however, that with most ancient readers this consonant $i$, while amalgamating mainly with the $a e$, emanated, as it were, from the $\bar{o}$, so that it becomes a difficult matter to state exactly what sounds or fractions of sounds entered into each syllable of this word, or indeed of any word. Let us now note the two instances of the word primus as used in the lines quoted above. Knowing the structure of the verses we discover that the latter part of the first primus filled a short metrical space, but the latter part of the second primus a long space. It is not reasonable to suppose that the parts in question were sounded identically in these unlike situations. We can only conclude that the final syllable of primus in the second case was closed, but in the first case had the effect of an open syllable, the $s$ being carried along to the next word.

This process whereby a final consonant is sounded somewhat in conjunction with a following initial vowel is termed linking (compare the French liaison). The final syllable of the first primus appears closed as the eye sees it on the page, but it is really open as the ear hears 
it in fluent reading. And what is heard is of course the true test. The poet takes care never to introduce a short syllable of this kind without providing an escape, so to speak, for the final consonant, that is, without having the next word begin with a rowel. To be sure, any rhetorical. pause that happens to occur after such a final syllable proves embarrassing, because it keeps the final consonant wholly with its word. Verses with a pause so introduced, however, are rare, and they are to be viewed in the light of 7 on pages $26 \mathrm{f}$. In such instances the poet has failed to bring the materials of language closely into harmony with the plan of the rhythm. That linking existed in Latin is well attested. Cicero, for example, (De Oratore, iii, 172) approves an orator's speech, " if the final and initial parts of words are so linked together that neither harsh collision nor marked hiatus is produced (sī verba extrēma cum cōnsequentibus prīmis ita iungentur, ut nēve asperē concurrant nēve vāstius dīlūcantur)." And Quintilian (ix, 4,44$)$ gives us clearly to understand that in fluent speech the concluding part of one word was closely joined with the initial part of the next word (extrēma ac prima coëunt). Therefore, under the conditions of fluent reading, a short syllable ends with a short vowel. And, since all other syllables are classed as long, a long syllable ends with a long vowel or with a consonant (see table on page 23).

We may now look at certain concrete cases under this last rule. In the Eneid, vi, 846, the verse concludes restituis rem-レ৩--, where the first syllable must be res-. The evidence for this is mainly as follows: $(a)$ the space to be filled is long, as the meter shows; but since 
the prefix $r e$ - in itself is short in quantity, the $s$ must have been uttered in such a way as to make the syllable closed and, therefore, long; $(b)$ in the Corpus Inscriptionum Latinarum, x, 7494, a line contains the word restituit, in which the stonecutter indicated the first syllable as res-; other inscriptions in which syllables are separated divide this word in the same manner. By such methods of study we have come to know how the various combinations of Latin consonants are to be managed in reading. Cases like in-ter, where only one pronunciation is at all probable, require no comment. Others call for special notice. The following combinations, occurring between two vowels of a word (whether simple or compound), are to be divided as indicated by the hyphen:

\begin{tabular}{|c|c|c|c|}
\hline$b-d$ & $(a b-d \bar{o})$ & $m p-t$ & $(\bar{e} m p-t u s)$ \\
\hline$c-n$ & $(O c-n u s)$ & $p-t r$ & $(\operatorname{cap}-\operatorname{tr} \bar{x})$ \\
\hline$c-t$ & $(\bar{a} c-t a)$ & $s-b$ & $($ Les-bos) \\
\hline$c-t r$ & $(v \bar{\imath} c-t r \bar{\imath} x)$ & $s-c$ & $(c r \bar{e} s-c \bar{o})$ \\
\hline$n c-t$ & $(s \bar{a} n c-t u s)$ & $s-c l$ & (As-clum) \\
\hline$d-n$ & $(A-r i-a d-n a)$ & $s-c r$ & $(A s-c r a)$ \\
\hline$g-n$ & $(c \bar{o} g-n \bar{a}-t u s)$ & $s-m$ & $(I s-m a-r u s)$ \\
\hline$m-n$ & $(o m t-n i s)$ & $s-p$ & $(p r o ̄ s-p e-r u s)$ \\
\hline$p-n$ & (The-rap-nae) & $s-t$ & (Cas-tor) \\
\hline$p-s$ & $(i p-s e)$ & $n s-t$ & (cōns-täns) \\
\hline$m p-s$ & $(A m p-s \bar{u} n c-t u s)$ & $n s-t r$ & (mōns-trō) \\
\hline$p-t$ & (cap-tus) & $s-t r$ & $(\text { cas-tra } a)^{1}$ \\
\hline
\end{tabular}

Combinations of consonants that are capable of being divided in more than one way will be discussed under section III below.

1 These examples are drawn in part from W. Dennison, "Syllabification in Latin Inseriptions," Classical Philology, Vol. I, No. 1. 


\section{VARIABLE SYLLABLES}

The process of composing verses may be regarded, from the mechanical point of view, as setting language to rhythm, as adapting the general material of language to the precise forms of meter. From time to time the poet places in his verse a word subject to two usages of pronunciation which affect the quantity of syllables, as for example mihi and mihi. Between them he must choose, and since it is unlikely that they have equal standing and favor, he naturally follows as a rule the more common usage. Sometimes, however, for the sake of overcoming some difficulty in metrical composition or from some other cause, he has recourse to the less common usage; that is to say, he adopts either a rare mode of pronunciation belongirng to his own age, an archaism, a local pronunciation, or, should a non-conforming word be sorely needed, a mode of utterance authorized by little more than what he makes out to be a possible pronunciation. Serving as they do the exigencies of versification, exceptional modes of pronunciation might at first be supposed to detract somewhat from the excellence of a poem. This is by no means always the case. At the hands of a poet who is master of his art, they are made not only to satisfy a practical end but to produce variety and occasionally still other desired effects. In the case of these variable syllables it is to be noted that the meter is a reader's guide to their quantitative value, whereas in all other syllables their value is a reader's guide to the meter. Syllables subject to variation may be classified as follows. 


\section{Cases Involving Vowels Variable in Quantity}

For purposes of discussion the cases which involve vowels variable in quantity are grouped under three heads. Under $A$ are discussed instances where two vowels are so placed that they fall sometimes in a single metrical space, and sometimes in two successive spaces. The discussion under $B$ treats of vowels which are long by nature according to one usage, and short by nature according to another. Under $C$ are considered vowels that are sometimes omitted altogether.

1. (Simple) Elision. When a word ended with a vowel and was followed by a word whose initial sound was a vowel, or $h+$ vowel, a Roman speaker was at liberty to keep the final and initial syllables separate or to blend them in sound - the latter, however, being the normal usage. The former mode of utterance resulted in what is called hiatus, the latter in elision. In elision the two syllables were practically reduced to one, whose quantity for purposes of versification was that of the second original syllable. The first of the two colliding vowels seems, as a rule, ${ }^{1}$ to have received a hurried partial pronunciation. In this way it was suggested to a hearer, but still did not occupy any appreciable time. (Compare grace notes in music.) Theoretically elision worked no change in the second vowel.

1 It is to be noted that the norm of elision is here set forth. When any rhythmical usage came into conflict with matters that the ancient reader deemed of higher importance, it doubtless failed of strict observance. 
That the first rather than the second vowel suffered curtailment or repression, as a rule, and that the second determined the quantity of the resulting syllable, is shown, among other ways, by such examples as the following:

artificumque manūs inter sē operumque labōrem. Verg. Aen. i, 455.

Here the sounds resulting from the elision must come within a short metrical space and therefore do service as a short syllable, even though the first vowel involved is long by nature. Further evidence that the first vowel was repressed is found in Quintilian's remark (ix, 4, 36): coëuntēs litterae, quae $\sigma v v a \lambda o \iota \phi a i$ dīcuntur, etiam lēniōrem faciunt ōrātiōnem, quam sĩ omnia verba suō fīne clüdantur. But that this rowel was by usage not entirely lost is implied in ancient comments on the subject. For example, the description of elision given by Donatus in his Grammar (page $396 \mathrm{~K}$ ) is "a gliding and gentle compression of concurrent vowels" (lũbrica lẽnisque collīsiō [vōcãlium concurrentium]).

Cicero has several passages bearing on elision in a general way. In the Orator, xliv, $149 \mathrm{ff}$, he expresses himself as follows:

Therefore the words [of a speech] are to be arranged in proper order, so that the last syllable of one word and the first syllable of the next may cling together as closely as possible and have sounds highly agreeable, again that their natural form and inherent symmetry may complete their own perfectly rounded period, and finally that the period in its completeness may have a neat and rhythmical eadence. ... It is, as it were, a kind of joinery.... As in reading the eye looks.forward, so in speaking the mind looks forward to what is to follow, in order that the coming together 
of final and initial syllables may not produce sounds marked either by hiatus or roughness. For however much charm or dignity there may be in the thought, still if it is expressed through words rudely combined it offends the ear, whose judgment is most fastidious. Indeed, the Latin tongue observes this to such a degree that no one is so unlettered as not to be inclined to blend (coniungere) vowels together.

Especially significant is the last expression. Mr. Sandys in his edition of the Orator, page 160, says:

This passage with its subsequent context is (with the exception of Lucilins) the earliest evidence now extant on the subject of Latin pronunciation. It leads us to infer that the Latin language, in its pure and madulterated form, could not endure a hiatus; that even rude and illiterate peasants habitually avoided it by blending together the consecutive vowels instead of sounding them separately.

The remark of Quintilian above suggests another fact in the nature of elision. It was originally employed by poets as a natural feature of the language, but in the course of time its presence in a verse, when skillfully managed, came to impart a special charm. Mr. Mackail (Latin Literature, page 9) observes that in reading the poetry of Ennius “one becomes aware ... of a strange and austere beauty of rhythm which is distinctly Italian. Specially curious and admirable is the use of elision,... . so characteristic alike of ancient and modern Italy. In Latin poetry Vergil was its last and greatest master; its gradual disuse in post-Vergilian poetry, like its absence in the earlier hexameters of Cicero, was fatal to the music of the verse, and with its reappearance in the early Italian poetry of the Middle Ages that music once more returns." 
Poets tend to avoid elision that would involve $(a)$ a final long vowel or diphthong and an initial short vowel, $(b)$ a final vowel that is immediately preceded by another vowel, (c) the first two vowels of a verse, and ( $d$ ) the last two vowels of a verse, except when the final word is est. In the case of this word elisio invcrsa takes place; that is to say, the ancient reader seems generally to have dropped the $e$ altogether, joining st to the preceding word; e.g. bona est $=$ bonast.

2. Nasal Elision (Ecthlipsis). When a word ending in a short vorel $+m$ occurred before a word beginning with a vowel, or $h+$ vowel, the final sounds were usually elided. The termination was probably not cut off altogether, the $m$ being uttered rapidly with a faint nasal sound. The latter part of the English word album, spoken rapidly in a sentence, gives a hint of such a sound. The basis of this figure of prosody lies in the fact that the Latin final $m$ under these circumstances was lightly sounded, the word concerned practically ending with a vowel. That this vowel was somewhat audible in nasal elision is attested by Gellius (xiii, 21) when he tells us that "turrim in praecipitī " was more agreeable to Vergil's ear than " turrem in praecipiti." When the enclitic word est was involved in nasal elision, the $m$ almost or quite vanished and the $e$ was dropped: thus bonum est became bonu(m)st.

3. Inter-Verse Elision (Synapheia) took place when two verses were joined together by elision, one element involved occurring at the close of a verse, the other at the outset of the next verse. Thus:

sors exitūra et nōs in aeternum

exsiliun impositūra cumbae. - Hor. Od. ii, 3, 27-28. 
In such pairs the first verse is said to be hypermetric. Eight instances of inter-verse elision are found in the first six books of the Eneid, namely : i, 332-333; 448-449; ii, 745-746 ; iv, 558-559; 629-630 ; v, 422-423; 753754 ; vi, $602-603$.

4. Half-Elision. Sometimes a final syllable which ended with a long vowel and did not have the ictus was made to occupy a short metrical space, its vowel being half elided before a word beginning with a rowel, or $h+$ vowel. The long vowel in this process lost part of its length and thus became consistent with the short space to which it had been assigned by the poet. For example:

vīctor apud rapidum Simoenta sub Ílio áltō. - Verg. Aen. v, 261.

Books i-vi of the Aneid show instances in iii, 211; v, 261 ; vi, 507.

5. Vowel Coupling (Synizesis). Within a single word two successive vowels ordinarily forming two syllables were sometimes made to occupy a single metrical space. Examples are deinde and alve⿳亠二口. Among the first six books of the Eneid cases occur in the following passages : i, 120 ; $131 ; 195 ; 256 ; 698 ; 726 ;$ iii, $602 ;$ v, 352 ; vi, $33 ; 280$; $412 ; 678$.

6. Hiatus. When a final rowel, or final $m$ preceded by a short vowel, was followed by an initial vowel, or $h+$ vowel, and the two syllables concerned were not made to blend in sound, the resulting gap was called hiatus. This means literally an opening, and derives its name from the fact that in the utterance of the sounds the vocal tube is continuously open.

Hiatus is not often found in Latin poetry, and even when introduced, one or more of the following circumstances 
generally minimize its objectionable eharacter: (1) it oceurs after a monosyllabic interjection ; (2) after a Greek word; (3) coincides with a casura somewhere near the middle of a verse; (4) occurs after a syllable having an ictus, especially a syllable containing a long vowel.

Examples of the foregoing cases are:

1. $\bar{o}$ et praesidium et dulce decus meum! - Hor. Od. i, 1, 2.

2. posthabitā coluisse Samō hic illius arma. - Verg. Aen. i, 16.

3. quid struit aut quā spē inimīcā in gente morătur. - ib. iv, 235.

4. The preceding example illustrates this point as well.

- Instanees of hiatus in the first six books of the Eneid are: i, 16 ; 405 ; 617 ; iii, $74 ; 606$; iv, $235 ; 667$; v, 735 .

7. Diphthong Resolution (Dialysis). Two vowels usually forming a diphthong were sometimes assigned by the poet to two adjoining spaces of a foot, and so separated into two syllables, as cö̈pit (Lucretius) for côै-pit. In any word affeeted by this usage we have the survival of an old form.

8. Archaic Quantity. (a) A syllable is sometimes found containing a vowel which was short according to the usage of classical times but long in an earlier age. Now and then an Augustan poet served his convenience by using. such a syllable with its archaic length. The syllable was generally reënforced by an ictus and often too by the fact that a pause in the sense immediately followed. For example:

Pergama cum peterēt inconcessōsque hymenaeōs.

Verg. Aen. i, 651, 
the last vowel of peteret being usually short in Vergil's time. Words with the ultima long according to this principle are found in the Aneid, i, 308; 651; ii, 369; v, $521 ; 853 ; \mathrm{vi}, 768$. It is probable that ancient readers sometimes produced the necessary length in these syllables by the process of arrested linking (see $\S 15$ below).

The following cases also are to be explained by the principle of archaic quantity, namely, when mih $\bar{\imath}$ is used for mihi, $t i \bar{\imath} \bar{\imath}$ for $t i b i, s i b \bar{\imath}$ for $s i b i, i b \bar{\imath}$ for $i b i, u b \bar{\imath}$ for $u b i, r \bar{e} \bar{\imath}$ for reī, or fidē for fidei, the second in each pair being the later form and during the classical period the prevailing usage.

(b) In the third person plural of the perfect indicative active the old ending -erunt, which in classical times had not yet been entirely superseded by -érunt, was sometimes used for metrical convenience, as for example in the Encid, ii, 774; iii, 48 ; 681.

9. Diminishing Quantity. Certain words contained vowels which were long in the classical period but became regularly short at a later time. Inasmuch as the change was then beginning to be felt, the Augustan poets sometimes used such vowels in their short form. For example, ünìus became ünius in the Anneid, i, 41; ii, 131; nüllius became nüllius in Hor. Epist. i, 1, 14; Ep. xvi, 61.

10. Unsettled Quantities in Certain Proper Names. In order to introduce certain proper names having quantities inconsistent with his meter, a poet occasionally took advantage of some unsettled pronunciation, or even changed the words arbitrarily. In the Aneid, for example, Asiae stands in iii, 1, but $\bar{A}$ sia in vii, 701; Diäna in xi, 582, but in Dī̄na in i, 499 ; ē̄̄s in ii, 417, ēōass in i, 489 ; Ital̄ in iii, 396 , but İtala in vii, 643 ; Lärĩnia in i, 2, but Lavīni 
in i, 258; Priami in ii, 56, but Priamidēs in iii, 346; Sicâ$n \bar{o} s$ in v, 24, but Sìcaniae in i, 557 ; Sìdōnia in xi, 74, but Sídoniās in iv, 75 ; Sychacum in i, 348, but Sy̆chaeus in $\mathrm{i}, 343$.

C

11. Vowel Omission (Syncope). Once in a great while a poet shaped a word to his meter by omitting a medial vowel that was short and unaccented, as in repostum (Aen. i, 26), used instead of the normal form repositum, and in periclum (Aen. ii, 709), used instead of periculum.

\section{Cases Involving Sounds Variable in Charaeter}

Certain sounds here come under consideration which are to be classed as vowels according to one usage, and as consonants according to another.

12. Vowel Hardening. The vowel $i$ or $u$ was sometimes made consonantal before another vowel: as ab-ie-te for $a$-bi-e-te. Thus the poet was able to use certain words that otherwise would have been unavailable in his verse. In the first six books of the Aneid cases occur as follows: i, $2 ; 73$; ii, $16 ; 442 ; 492$; iii, $136 ; 578$; iv, 126 ; $168 ; 686 ; \mathrm{v}, 432 ; 589 ; 663 ; 697$.

13. Consonant Softening. Conversely, the consonant $i$ or $u$ was sometimes intended by the poet to be sounded as a vowel before another vowel, thus giving an additional syllable: as si-lu-ae (Hor. Ep. xiii, 2) for sil-vae.

\section{Cases Involving Consonants Variable in Grouping}

Here we are concerned with certain consonants of Roman speech that usually were joined to vowels in one 
way, but sometimes in another. The subject may conveniently be considered under three heads. Under $A$ are treated instances of two successive consonants, or a double consonant, usually uttered within a single metrical space, but sometimes divided between two successive spaces. Under $B$, instances of a single liquid or $s$ (occurring between vowels) usually joined to the following vowel, but sometimes uttered partly with the preceding rowel and partly with the following one. Under $C$, instances of a single final consonant (occurring before an initial vowel) usually subject to the process of linking, but sometimes not allowed to amalgamate with the following word.

\section{A}

14. Divisible Consonant Groups. (a) Here are to be classed the so-called common syllables, which may be described as follows. The conditions for such a syllable were a succession of four elements, namely, short vowel, mute, liquid, vowel (either long or short); secondly, for such a group only a few special combinations of mute and liquid, such as $c l, p l, t l, b r, c r, g r, p r, t r$, were made valid by usage; thirdly, if the common syllable was short in a given passage, the syllabic division was $v$-mlv $(v=$ vowel, $m=$ mute, $l=$ liquid), but if such a syllable was long, the division was $v m$-lv. Thus patris when used to fill out the time of an iambus was sounded pa-tris, but when used to fill out a spondee it became pat-ris. ${ }^{1}$

1 Êvenit ut metrĩ quoque condiciō mūtet accentum: pecudēs pìctaeque volúcrēs; nam volucrēes mediā acūtā legam, quia, etsī nātū rā brevis, tamen positiōne longa est, nē faciat iambum, quem nōn recipit versus hērouus. - Quintilian, i, 5, 28. 
The following verses exhibit common syllables used in both their short and long forms:

adflìctus vītam in te-ne-brīs lūctūque trahēbam.-Verg. Aen. ii, 92. noctem hiememque ferēns et inhorruit unda te-neb-rīs. - il. iii, 195. Hỳrtacidae iuvenis vo-lu-crēs dīverberat aurās. - ib. v, 503. cum tacet omnis ager pecudēs pīctaeque vo-luc-rēs. - $i b$. iv, 525. religiōne sa-crae et saevi formīine Martis. $\_i b$. vii, 608. effigiēs sac-rae dīrum Phrygiīque Penātēs. — i i . iii, 148. nātum ante ōra pa-tris pat-ren quī obtruncat ad ārâs. —ib. ii, 663.

The conditions of a common syllable are not present in $\bar{a}$-crior of the following verse, the initial vowel being long and the syllable constant in form.

ācrior ad pūgnam redit ac vim suscitat îra. - ib. v, 454.

Nor are they present in compounds like ab-rumpō. If the prefix terminated with a short vowel and a mute, the second member beginning with a liquid and a vowel, the division of sounds was always such as to put the mute and liquid into separate syllables.

(b) Once in a while the poet placed in a long metrical space the final syllable of a word ending with a short vowel, the next word, however, beginning with a mute and liquid, or $s$ and another consonant. The intention seems to have been in such cases that the initial consonant should be uttered in conjunction with the preceding short vowel, thus making the final syllable practically closed and therefore long. For example:

Crētesque Dryopesque fremunt pīctīque Agathyrsī.

Verg. Aen. iv, 146.

Brontēsque Steropēsque èt nūdus membra Pyracmōn.

ib. viii, 425 . 
B

15. The Continuable Consonant. The poet sometimes placed in a long metrical space a syllable ending normally in a short vowel, the next syllable, however, beginning with a single consonant of a certain kind, chiefly, a liquid or $s$. The intention seems to have been that the reader should join the said consonant with both the preceding and the following vowel. Such a prolongation of these particular consonants is possible by virtue of their peculiar nature. The syllable in the long metrical space thus became closed and therefore long. For example:

līminaque laurusque deī tōtusque movērī. - Verg. Aen. iii, 91 . Trōas reliquiās Danaum atque immītis Achillī. - ib. i, 30. dōna dehinc aurō gravia sectōque elephantō. —ib. iii, 464.

The sounds -que lau- were heard somewhat as -quellau-, reli- as relli-, and - $a$ sec- as -assec-. These cases, however, were doubtless open to another treatment at the pleasure of a reader; if the cæsura (see page 46) was made prominent, the preceding metrical space might be filled partly with the vowel (the more easily because it had an ictus) and partly with the pause.

\section{C}

16. Arrested Linking. The poet sometimes placed in a long metrical space the final syllable of a word ending in a single consonant preceded by a short vowel and followed in the next word by an initial vowel. In fluent reading such a consonant would normally be linked in sound with the following initial vowel (see page 29), a mode of utterance that would leave the final syllable open and short. 
Sometimes, through the demands of meter, the consonant was confined to the preceding word, whose final syllable then became closed and therefore long. Such a syllable generally had an ictus and often too was followed by a pause in the sense. The long metrical space was thus duly filled with the necessary amount of sound. For example :

lītora iactētur odiîs Iūnōnis inīquae. — Verg. Aen. i, 668.

See also $2 b$. i, 478 ; ii, 411 ; 563 ; iii, 112 ; iv, 64 ; 222 ; v, $284 ; 337 ;$ vi, 254.

\section{FEET}

Among the various divisions of time in a quantitative rhythm the unit, as we have seen, is the foot. The component parts of this member are the spaces (of time) already described (see page 24). Within a single series feet have not only sameness, or at least similarity, of make-up; but equal. length and unity. A feature which emplasizes these qualities is the so-called ictus, ${ }^{1}$ which is a slight extra stress or loudness (much milder than in English verse) given systematically to a certain syllable of the foot. Phythmical pauses (page 10) do not intervene

$1 \mathrm{An}$ ictus involving stress seems to belong to Latin verse from several lines of evidence, but especislly from such ancient testimony as the following: Cicero (De Or. iii, 47, 182), regarding iambic and tribrach feet says, "sẹl sunt insignnès percussiōnës eōrum numerōrum." And in the same passage $(48,185)$ he considers a certain kind of speech rhy̆thmical, "quod habet quāsdam imprcssiōnès et quod mêtîri possumus intervallis aequālibus." Quintilian (ix, 4,75 ) says of a trimeter verse, "sex enim pedēs, trēs percussiōnēs habet." And again $(x i, 3,108)$ in another connection, "sunt quaedam latentēs sermōnis percussiōnēs et quasi aliquī pelēs." And again (ix, 4, 136) "[iambi] frequentiorem quasi pulsum habent." 
between the individual feet of a series, the transition from one foot to another being sufficiently marked by their recurring form. The name thesis ( $\theta$ '́ $\sigma \iota$, down-beat) is applied to that space of a foot which has the ictus, the remaining space or spaces being called the arsis (ápoıs, up-beat). When the arsis precedes the thesis in a foot (as in the anapest), the rhythm is said to be ascending; when the reversed order appears (as in the dactyl), it is descending.

The feet commonly used in Latin poetry are shown in the following table:

\begin{tabular}{|c|c|c|c|c|}
\hline Name of foot & $\begin{array}{l}\text { Total length } \\
\text { measured } \\
\text { in 'short } \\
\text { spaces' as } \\
\text { units of } \\
\text { time }\end{array}$ & $\begin{array}{c}\text { Internal time relations } \\
(\mathrm{s.}=\text { 'space') }\end{array}$ & Represented & $\begin{array}{c}\text { For } \\
\text { example }\end{array}$ \\
\hline 1. Trochee & Three & Long s. + short s. & $-\cup$ or & ille. \\
\hline 2. Iambus & Three & Short s. + long s. & $\cup-\quad$ or & ferō \\
\hline 3. Tribrach & Three & $\begin{array}{l}\text { Short s. + short s. } \\
+ \text { short s. }\end{array}$ & $\cup \cup \cup 01$ & itaque \\
\hline 4. Dactyl & Four & $\begin{array}{l}\text { Long s. + short s. } \\
+ \text { short s. }\end{array}$ & $-\cup \cup$ or & dènique \\
\hline 5. Anapest & Four & $\begin{array}{l}\text { Short s. + short s. } \\
\quad+\text { long s. }\end{array}$ & $\cup \cup$ or & alubitō \\
\hline 6. Spondee & Four & Long s.tlongs. & - & $v \bar{e} r \bar{o}$ \\
\hline
\end{tabular}

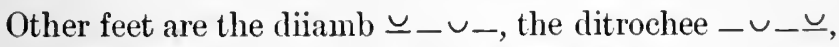
the choriamb - $\cup-$, the Ionic a maiore -- $\cup$, the Ionic a minore $\cup \cup--$, the antispast $\checkmark--\cup$, the Cretic $-v_{-}$, the Bacchius $v_{-}$, the Molossus - -, , the first pæon $-\cup \cup \checkmark$, the fourth pron $\cup \cup \cup-$, and the proceleusmatic $\cup \cup \cup \cup$. 
As a rule, a poet avoids making successive words each coincide with successive feet in the opening and middle parts of a verse. When a word and a foot end coincidentally, the resulting break in the rhythm is called a diceresis, but when a word ends within a foot, the break is called a casura. Cesuras tend to occur more often than diæreses, especially in the opening and middle parts of a verse. A masculine cesura, so called from its strong and firm sound effect, is one occurring between a thesis and an arsis. A feminine cesura, with its light and rapid effect, is one occurring within an arsis. A cesura is called trithemimeral, penthemimeral, or hepthemimeral according as it occurs after the third, fifth, or seventh half-foot of a verse.

As the feet of a rhythm succeed one another they tend to fall into groups marking other divisions of time which have greater and greater amplitudes. Each division has its own unity, which, however, is not dominant enough to do away with the more comprehensive unity of the next higher division. The colon is composed of feet and the verse of cola. Out of verses, themselves sometimes combined into strophes, springs the poem.

\section{Cola}

A colon is a rhythmical division arising from a regular grouping of feet. The number of feet included in each colon varies with different rhythms but in any case it is not less than two nor more than six. These limits depend on the amount of speech that can be uttered comfortably without taking breath, on the range of sounds that makes an agreeable phrase (in the musical sense), and on other conditions of the human ear and voice. The unity of a 
colon is signalized sometimes by rhythmical pauses that precede and follow it (see 1, page 10), always by the fact that one of the ictuses within it is made prominent above the others. In trochaic or iambic rhythm a colon may have six feet, but in dactylic or anapestic rhythm it may not extend beyond five. The dactylic hexameter, which exceeds the limits of a single colon, is thought to have arisen from the union of two cola, each containing three feet. Greek poetry now and then shows an hexameter in which the opening colon seems to embrace four feet and the other colon two feet. This type, however, is rare in Latin and may here be neglected.

\section{VERSES}

But a succession of feet freed from a certain monotony by being grouped into successive cola does not completely satisfy the poet's feeling. Still other modes of grouping are necessary. Accordingly, to obviate fatigue as much as possible for the reader or singer, to increase the effect of variety, to bring about a still more pleasing and artistic form, cola in their turn are combined into verses. The length of a verse is determined by certain limitations in man's powers, in particular by the extent of sustained effort that is natural to the ear and voice. Accordingly, the number of cola belonging to a verse is one, two, or three; in most rhythms, as in the dactylic hexameter, two. A verse is generally written as a separate line on the page, in keeping with the derivation of its name from versus, a turning.

In some rhythms an ancient reader seems to have felt the feet singly, while in others they ran in pairs. Hence 
the length of a verse is indicated in two ways. The measure employed in iambic, trochaic, and anapestic rhythms consists of two feet, or a dipody. An iambic dimeter, for example, is two measures long but has four feet. In other rhythms the measure consists of a single foot. A dactylic hexameter is six measures long and has six feet.

The complete name of a verse generally involves (1) an adjective showing the kind of feet it contains - if these vary the adjective should describe the fundamental foot; (2) a noun denoting the length of the verse; and (3) an adjective describing the conclusion of the verse, namely, acatalectic if the final foot is complete, catalectic if the latter part of it is wanting. In case the third part of the name is not expressed, it is understood to be acatalectic. A dactylic hexameter, then, is a verse whose fundamental feet are dactyls, whose length is six measures, indicating six feet, and whose last foot is complete. An iambic trimeter catalectic has the iambus as its fundamental foot, has three measures and six feet, the last one being incomplete. For example:

vocātus atque nōn vocātus audit. — Hor. Od. ii, 18, 40.

There remain to be considered several other matters pertaining to the form and character of the rhythmical division now under discussion. While it is true that the verses of a poem are intended to succeed one another in compact and closely connected series, still no mode of reading is justifiable that fails to allow each verse to make its complete and individual impression. Thus there arises an important use of the rhythmical pause (see page 10). Aside from the rare and exceptional conditions described 
in $\$ 3$ on page 36 , such a pause is uniformly to be observed at the close of a verse; moreover, this holds even when the sense at that point does not require a stop.

The fact that rhythmical pauses intervene between verses, and that in general one's rhythmical sense does not measure exactly the final sound in a series, makes it unnecessary always to fill out the last metrical space of a verse with the precise length of sound that theoretically belongs within it. Thus a certain elasticity in the length of the syliable is permitted at that point, and yet the time relations of the rhythm as a whole are kept sufficiently true. To this syllable of indifferent length, standing within a final metrical space of a verse, is given the name syllaba anceps. This final syllable is also responsible for another sound effect permitted between verses but generally avoided within a verse. That is, the poet is at liberty to end one verse with a vowel, or a vowel $+m$, and to begin the next with a vowel, or $h+$ a vowel. This is called inter-verse hiatus.

A verse, except it be one of very limited range, is regularly so composed that a reader, without doing violence to the sense or the rhythm, may pause for an instant in the midst of its course. There results a feature which contributes at once to variety of effect and ease of delivery. In some types the pause occurs at a diæeresis. An example is the dactylic pentameter; here the two plirases of sound that result from the division coincide with the two cola that constitute the verse. In other types - and now we come upon a very numerous class - the pause occurs at a cæsura. An example is the dactylic hexameter; the poet is here bound to make the arrangement of words 
consistent with a pause in the third or fourth foot, the resulting phrases of sound falling slightly at variance with the two cola of the verse.

\section{Groups OF Verses}

A Latin poem involves either verses of a single kind arranged in series of indefinite length, as in the AEneid, or verses of different kinds arranged in series of definite length, as in many Odes of Horace. In the first instance the arrangement is said to be stichic, in the second the verses are arranged in strophes or stanzas. 


\section{Part II. The Dactylic Hexameter and Pextameter}

Two kinds of feet are involved in these types of verse: the dactyl $(\mathscr{\cup} \cup)$ and its metrical equivalent the spondee (-). The fundamental foot is the dactyl, for which, however, the spondee is very often substituted. In the Aneid dactyls stand to spondees in about the ratio of thirteen to eleven.

\section{THE DACTYLIC HEXAMETER}

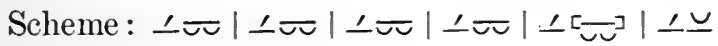

The rhythm is illustrated by the following selection, in which syllables having the ictus are marked underneath by dots.

Arma virumque canō, Trōiae quī prīmus ab ộnis

İtaliạm, fātộ profugụs, Lāvịniaque vẹ̄nit

lītora, multum ille et terrịs iactạtus et altō

vì superum saevae inemorem Iñūọnis ob ị̂ram;

multa quoque et bellō passus, dum conderet urbem

ịnferrẹtque deọ̄s Latiō, genus ụnde Latịnum

Álbānịque patrệs atque ạtae moenia Rộmae.

Mụsa, mihī causạs memorạ, quō nụmine laesō

quidre dolẹns, rēgīna deum tot volrere cāsūs însīgnem pietāte virụm, tot adịre labộrēs impulerit. Tantaene animịs caelestibus ịrae?

Verg. Aen. i, 1-11. 


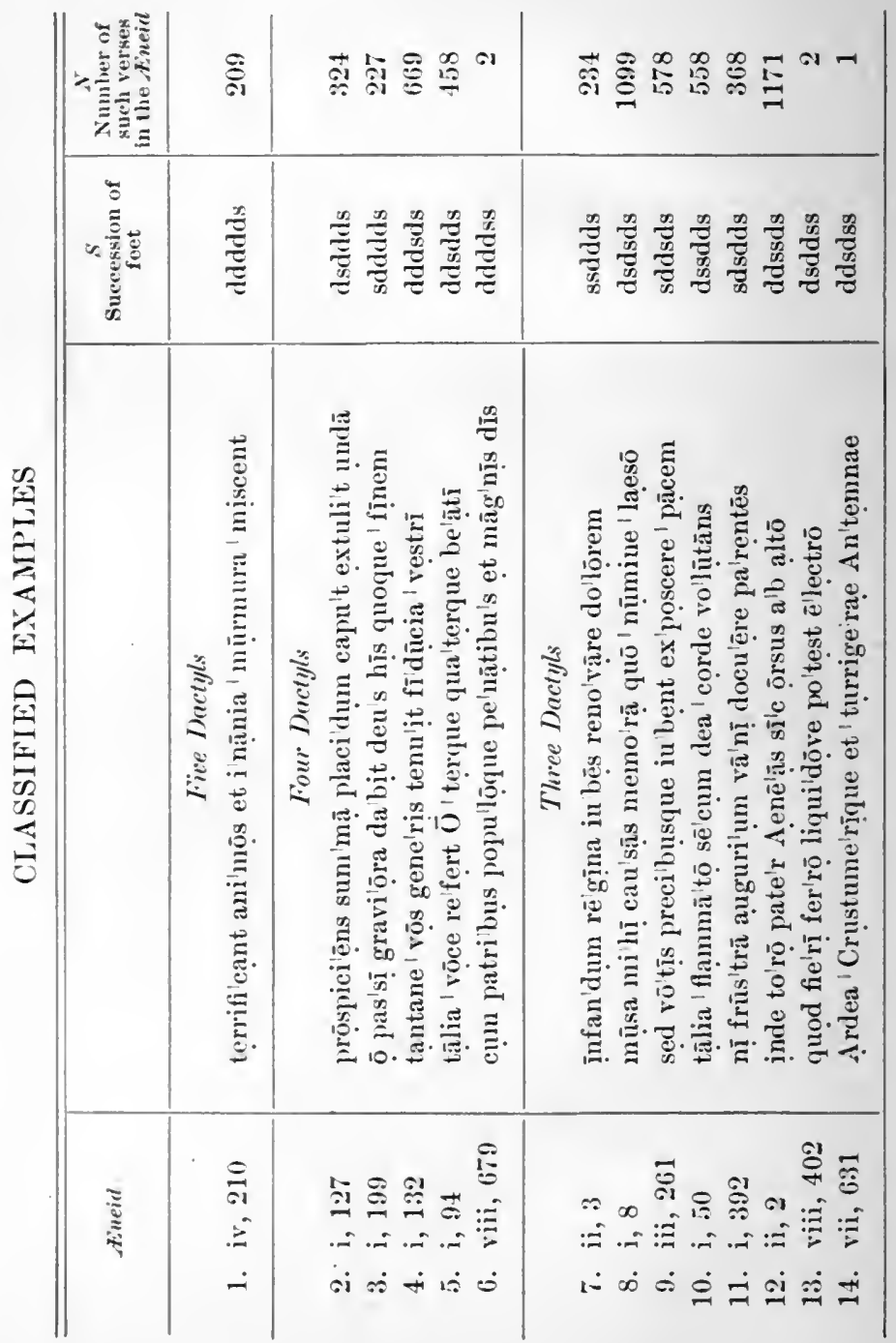


DAC'TYLIC HEXAMETER AND PENTAMETER 53

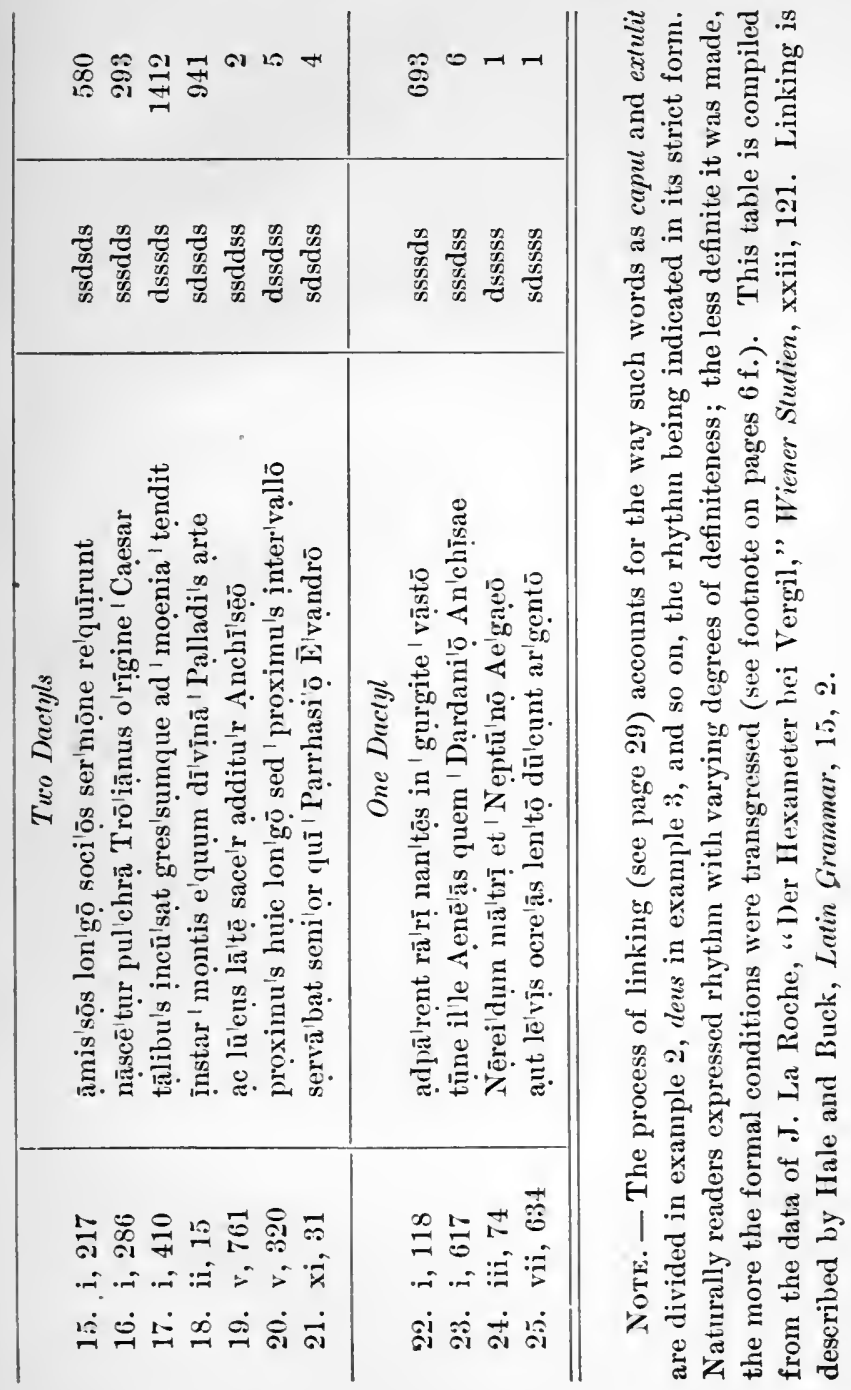


These twenty-five examples from the Eneid exhibit many characteristics of the verse under consideration. The dactylic hexameter consists of two cola having three feet each. Within perpendicular lines are represented the sounds that measure off the several feet. Column $S$ gives the succession of dactyls and spondees in each case; column $N$ the number of verses in the Eneid having the given succession, thus showing the favor it enjoyed.

The first foot, it will be seen, may be either a dactyl or a spondee. The same is true of the second, third, and fourth feet. In fact the same is true of the fifth foot, but with an important difference of degree; for, by reference to column $N$, it becomes evident that a spondee in that place is extremely rare. When a spondee is so placed, the line is called a spondaic verse. The final foot is measured in every case by means of two syllables. In most instances both are long and we have a normal spondee. This is the case not only in examples 1 and 2 but also in 3 and 17, a closed syllable being long. In some instances, like example 18, the first syllable is long and the second short. The presence of such a final syllable is to be explained on the principle of the syllaba anceps as set forth on page 49 .

The end of any long verse is naturally marked by a certain closing cadence. This fact helps to explain several features in the structure of the dactylic hexameter: $(a)$ the last two feet are fixed in kind and arrangement, - a dactyl and a spondee, the more tranquil foot coming last; (b) the words falling within these feet are, as a rule, either dissyllabic or trisyllabic; $(c)$ ictus and word accent here usually coincide - in the main a natural result of the 
two foregoing conditions, and yet one that comes to be enjoyed along with effects that the poet has attained in a more conscious and deliberate way. By way of contrast the other part of the verse has the following effects: the first four feet have no uniform arrangement; the words within those limits vary widely in length; ictus and word accent may or may not coincide, the poet's preference being to have them fall separately.

A monosyllable rarely stands at the end of the verse. Such a word in that position is likely to be enclitic; moreover its abrupt effect is often further softened by another monosyllable occurring in the same foot, as in

prōspectum lātē pelagō petit Anthea sī quem. - Verg. Aen. i, 181.

The poet, however, sometimes departs from this usage when he wishes to produce an impressive (Aen. i, 65 , and example 6 in the table above) or surprising effect. Horace's verse,

parturient montēs, nāscētur rīdiculus mūs. - A.P. 139,

conveys its ludicrous surprise in part by its rhythmical form, and Vergil's

quae vigilanda virīs vel cum ruit imbriferum vēr. $-G$. i, 313,

has an unexpected close that comes over one very much like the thing he is mentioning, spring showers.

It is rare to find at the end of a verse a word of five syllables, still more so one of four syllables. Spondaic verses, however, in conformity with a usage set in Alexandrine Greek poetry, rarely end with a trisyllable, almost never with a dissyllable, but normally with a quadrisyllable (and this word is often a proper noun or proper 
adjective). "Spondaic verses are comparatively rare in Ennius and Lucretius, but become more frequent in Catullus [a mark of his fondness for Alexandrine poetry]. They are not common in Vergil, Horace, Propertius, and Ovid, and do not occur at all in Tibullus. Persius has one spondaic verse, Valerius Flaceus one, Claudian five, Silius Italicus six, Statius seven." - Lane, Latin Grammar, 2567.

Many dactyls in a verse give the effect of lightness or rapid motion, as in

quadrupedante putrem sonitū quatit ungula campum.

$$
\text { Verg. Aen. viii, } 596 .
$$

Many spondees, on the other hand, give the effect of solemnity or slow motion, as in

vultī quō caelum tempestātēsque serēnat. —ib. i, 255.

The first four feet of the verse are normally composed in such a way that cresuras outnumber diæreses. Should direreses be in excess, the limits of the feet would be too sharply defined; the structure would be thrown into too bold a relief; and the verse would lack variety, fluency, and musical quality, as in the following example:

sparsis hastīs longīs campus splendet et horret.

Enuius, Fragm. Varia, 14 (Vahlen).

Cesuras, as appears in the table of examples, are found in all parts of the verse. Such a break occurs nearly always in the third or fourth foot, but very infrequently in the sixth. This treatment results from a feeling that any verse having considerable range can not be agreeably read as a single movement, unbroken and evenly sustained.1

${ }^{1}$ Incissiōnēs etiam versuum, quās Graecī romàs vocant, ante omnia in hexametrō necessã riō observandae sunt. - Marius Victorinus, i, 19. 
Hence, the dactylic hexameter is composed of two parts, each signalized by containing a more or less compact group of words. The break between these parts gives a reader an opportunity to take breath. Since a diæresis employed for this purpose would impair the rhythmical flow of the rerse as a whole, this break is normally a cæsura. It is distinguished from other cæesuras by the name main cæsura. It is usually located at the middle of the third foot, in which case it is called a penthemimeral cresura; less often it occurs at the middle of the fourth foot and receives the name hepthemimeral cesura. Within the second part of the verse an opportunity to take breath is sometimes offered between the fourth and fifth feet. Such a break is called a bucolic diceresis, because of its rather frequent use among Greek bucolic poets. It is rare among Latin poets, except Juvenal. When it does occur, it is generally secondary in importance to a cæsura in the second or third foot of the verse, as in

ite domum saturae, venit Hesperus, ite capellae.-Verg. E. x, 77 .

The frequent use of the penthemimeral cæsura is further explained by the poet's desire to build the verse of two parts, a shorter followed by a longer. The reversed order (brought about, for example, by the hepthemimeral cæsura), if often repeated, would be less happy. Even artistic Latin prose is subject to much the same law. In discussing the characteristics of the period Cicero says (De Oratore, iii, 48,186 ) that the effect is most agreeable when shorter word groups are followed by longer.

Elision is freely admitted into the hexameter by classical poets, especially by Vergil, and is most common within the second, third, and fourth feet. 
The hexameter exhibits almost endless variety. For example, the character of the feet and the range of the verse often allow repeated expressions to receive different metrical treatment, as in the following instances:

prịnus humum foditō prìnus dēeècta cremātō. - Verg. G. ii, 408. mịrantur dōna Aenēae mìrantur Iūlum. — id. Aen. i, 709.

multa super Priamō rogităns super Hectore multa. - i $\boldsymbol{i}$. i, 750.

To take another feature, the verses constantly undergo changes of form, resulting partly from the various arrangements of the included dactyls and spondees, partly from the shifting main cesuras, which, as we have seen, may assume several different positions. Again, variety springs from the great flexibility of the first four feet of the verse as contrasted with the final two: within the former portion a free arrangement of dactyls and spondees is followed within the latter by a fixed and orderly arrangement; a varied location of word accent with reference to ictus is followed by a conjoining of these elements; words widely diverse in length are followed by words of fairly uniform length; a somewhat free use of elision is followed by a less free use. After the first four feet with their individual qualities, the ear finds a peculiar rest and pleasure in the last two with their uniform sequence, their tranquil word lengths, their united ictuses and word accents, and their subsiding cadence. Each part freshens the ear and mind for a renewed enjoyment of the other, and yet the two are sufficiently homogeneous so that the unity of the verse is not lost.

Anong the Greeks and Romans the dactylic hexameter verse became a favorite form for poetic expression. From 
the Homeric period down to the Middle Ages man committed to its cadences much of his most inspired thought. Of this the choicest portion has happily escaped neglect, one generation cherishing its heritage for the next, in the earliest times by the power of memory, later by the written or printed page, until at last it has come into our hands. Wonderfully impressive are the associations of this world-old world-wide song.

\section{THE DACTYLIC PENTAMETER}

The-name pentameter, though brought into use by the ancients themselves, hardly gives a correct impression of the verse, which has two cola of equal length and seems to be a hexameter with the third and sixth feet modified. For purposes of reading, the normal scheme was:

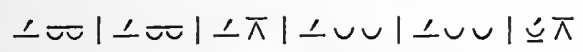

When, however, this verse was employed in song, the syllables within the third and sixth feet naturally were affected by protraction and became tetrasemic, thus filling the divisions entirely with sound. Under these conditions no pause $(\pi)$ was required. A reader was always at liberty to treat the feet in a similar manner. ${ }^{1}$

This verse alternates with the dactylic hexameter, thus forming the elegiac strophe. The following illustration is from Ovid (Fasti, i, 1-10):

Tẹpora cụm causị̂ Latium dỉgesta per ạnum lapsaque sub terrậs ortaque sịgna canam.

Ẹxcipe pạacātọ̄, Caesar Germānice, vụltū hộc opus, ẹt timidae dịirige nậvis itẹr;

${ }^{1}$ See Allen and Greenough, New Latin Grammar, 616, b. 
ơficiōque, levem nōn ậversạtus honộrem, hựe tibi dẹvōtō nụmine dexter ades.

Sạcra recọgnōscẹs annạlibus ệruta prị̂scīs, êt quō sịt meritọ quaeque notăta diệs. Inveniês illịc et festa domestica vộìs ; saepe tibì pater est, saepe legendus avus.

The scheme, then, for the strophe as a whole is :

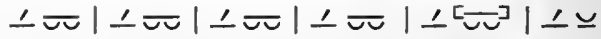

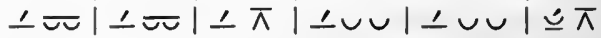

In the first colon spondees may take the place of dactyls. Unlike the dactylic hexameter, this verse allows a reader to pause for breath at the diresis between the cola. As a rule, the concluding word of the second colon in Ovid is a dissyllable. The word lengths of the first colon are usually made to differ from those of the second colon. The halves of the verse are sometimes bound together by two similar sounds falling one in the first colon and the other at a corresponding point in the second colon, as

lïlera perpetnōs ambulat illa viās. - ib. i, 122.

lüdit et in pratiss lüxuriatque pecus. - $i b . \mathbf{i}, 156$.

The same end is often attained by chiasmus or some other rhetorieal figure whose elements fall partly in the first and partly in the second colon, as in

officimure forī mīlitiaeve labor. - ib. i, 302.

summaque Pèliaeus sīdera tangat apex. - ib. i, 308.

The elegiac strophe was both imitated and described by Schiller in the following lines:

In IIexameter steigt des Springquells flüssige Süule, Im Pentameter drauf fält sie melodisch herab. 
This couplet was turned into English by Coleridge in his Ovidian Elegiac Meter:

In the hexameter rises the fountain's silvery column,

In the pentameter aye falling in melody back.

Temnyson afterwards recast the same with a view of illustrating more accurately the relations of ictus and word accent :

Up springs hexameter with inight, as a fountain arising, Lightly the fountain falls, lightly the pentameter.

As here observed, the pentameter is by nature a clausula and the sense is likely to be completed at the end of each couplet. Hence elegiac poetry abounds in rapid, epigrammatic thought.

Who invented this form of verse we can not say, any more than could Horace in his time :

quis tamen exiguōs elegōs ēmīserit anctor, grammaticī certant et adhŭc sub iūdice lis est.-A.P. $77-78$.

Three periods, however, of full bloom may be traced in the long unbroken favor that it lias en joyed: the Ionic elegy of the seventh and sixth centuries before Christ, marked by Callinus, Tyrtæus, Mimnermus, Solon, Phocylides, Theognis, Xenophanes, Simonides of Amorgus, and others; the Alexandrine elegy of the third century, marked by Callimachus, Philetas, Eratosthenes, Parthenius, and others; the Roman elegy, marked by Catullus, Tibullus, Propertius, Ovid, Martial, and others. 


\section{PRACTICAL HINTS ON READING LATIN} POETRY

1. Read aloud constantly, striving to grasp and express the meaning.

2. Do not drop the voice at the end of a verse, unless the sense requires it.

3. Let the words fall into their proper sense groups.

4. The play of intonation should be in keeping with the thought. Let the voice take up the emphasis implied in prominently situated words, separation of nouns from modifiers, antitheses, and correlated expressions.

5. The word accent, involving increased stress and raised pitch, ${ }^{1}$ should be sounded lightly.

6. The ictus, involving increased stress, should be lighter than the beat in English verse. The rhythm is not largely dependent upon it, being produced mainly by syllabic quantities. Word accent is a means of pointing the thought, and to that extent is free, while ictus points the rhythm, and so is bound. They are related as content is to form.

7. Utter words in such a way that a hearer may be left in no doubt as to the form and duration of each syllable. From the very outset the student should be accustomed to a consistent pronunciation of the Latin language, syllables being distinct and time values true. With this kind of training he will

1 W. M. Lindsay, The Latin Language, page 152 ; R. S. Radford, "Studies in Latin Accent and Metric," Trans. Am. Phil. Assoc., 1904. 
pass naturally and easily from prose to poetry. He will speak the words of a verse in the ordinary way and the rhythm will come largely unbidden. The proper time values of Latin words may be illustrated as follows : pater has the same duration as the last two syllables of Iuppiter; itaque the same as the last three syllables of peremptorily; similarly $q u \bar{i} n=$ cease, $a m \bar{o}=$ meadow (if we may change the pronunciation slightly and sound it $\left.m \check{e}^{\prime}-d \bar{o}\right)$, prīmī $=$ seesaw, amici = a May Day, recēperunt $=$ a low rowboat.

8. Make the quantities determine the rhythm, and not the rhythm the quantities. The only situations in which the rhythm should be relied upon to determine the quantity are in the "variable syllables" (see pages $32 \mathrm{f}$.).

9. Do not orerdo the rhythm. It is only an accompaniment (see page 21).

10. Read dactylic hexameter and pentameter verse in $\frac{4}{8}$ time, and not as students are often prone to do in $\frac{3}{8}$ time.

11. Read in a somewhat measured, flowing manner. Poetry has more of a singing quality than prose. ${ }^{1}$

1 Quintilian (i, 8, 1-2) has the following to say about reading poetry: "In this matter it is impossible, except in the course of practice itself, to teach a boy to know where he should check his breath, where he should divide a verse, where one thought ends and another begins, where the voice should be raised or lowered, what intonation belongs to each part, what should be uttered quickly and what slowly, what in an impassioned manner and what calmly. There is then but one thing that I can lay down on this subject, namely : if he is to be able to do all these things, let him understand the 
12. Commit to memory farorite passages and recite them until they convey the spirit of the literature.

subject-matter. Furthermore, his reading should be vigorous. It should combine dignity with a certain pleasant appeal to the senses. Reading poetry should differ from reading prose, for the former is song and the poets say they sing; on the other hand, it should not degenerate into singsong or be weakened, as is now the case with many people, by an affected modulation of the voice. There is a tradition that some one was once rendering a poem in this extreme style and that Gaius Casar, then a boy, addressed to him a very happy remark, saying: 'If you are singing, you sing badly; but if you think you are reading, the fact remains that you sing." ", 


\section{INDEX}

acatalectic, 48

alliteration, $2 ; 13 ; 21$

arsis, 45

assonance, $13 ; 21$

cæsura, $11 ; 46$; 49 ; 56 ; main,

$57 ; 58$

catalectic, 48

clausula, 61

colon, $46 ; 54 ; 59 ; 60$

consonant, 23 ; between vowels,

28 ; groups, 30 f.; $40 ; 41$;

softening, 40

correlated expressions, 16

dactylic verse, hexameter, 49;

$51 \mathrm{f}$.; pentameter, $49 ; 59 \mathrm{f}$.

diæresis, 11 ; $46 ; 49 ; 56$; bucolic,

57

dialysis, 38

diphthong, 23 ; resolution, 38

duosemic, 25

ecthlipsis, 36

elision, $33 \mathrm{f}$; 57

emplrasis, iii ; 2 ; 62

feet, $24 ; 44$ f. ; 54 f.

half-elision, 37

hepthemimeral, 46

hiatus, $35 ; 37 \mathrm{f}$.

ictus, $44 ; 54 \mathrm{f} . ; 62$

inter-verse elision, 36

inter-verse hiatus, 49 lengthening, $18 ; 25 ; 38, \S 8 ; 41$, $\S 14 ; 43, \$ \$ 15$ and $16 ; 59$ linking, $28 \mathrm{f}$; ; arrested, 43 liquids, $41 ; 43$

measure, 48

meter, 8

monosemic, 25

mora, 24

mutes, 41

nasal elision, 36

pause, $10 ; 48 ; 59$

penthemimeral, 46

poem, 3 f.; $21 ; 46$

quantity, 22; 63 ; archaic, 38; diminishing, 39 ; unsettled, 39

reading, $1 \mathrm{f}$; $62 \mathrm{f}$.

rests, $10 ; 24$

rhythm, accentual, 9; ascending,

45 ; auxiliary factors, 10 ; its

complexity, 7 ; descending, 45 ;

and ideas, 19 ; instinctive, 4 ;

17 ; and memory, 5 ; and meter,

$8 \mathrm{f}$.; in music, 6 (footnote); in

prose, 21 ; quantitative, 10

rime, $13 ; 21$

$\mathrm{s}, 42 ; 43$

shortening, 18 ; $25 ; 33$, I

silence, 10

sound parallelism, 13

space (metrical), 24 


\section{INDEX}

stanzas, 50

stichic, 50

stops, 10

strophes, $46 ; 50 ; 59$

syllable, $5 ; 22$; anceps, 49 ; 54

closed, 25; 54 ; common, 41 ;

long, 23 ; 30 ; open, 25 ; short,

23 ; 30 ; variable, 18 ; 32 f.; 63 synapheia, 36

syncope, 40

synizesis, 37 tetrasemic, 25

thesis, $\mathbf{4 5}$

time, 24

trisemic, 25

trithemimeral, 46

verse, 47 f. ; names, 48 ; spondaic, $54 \mathrm{f}$.

vowel, 22 ; coupling, 37 ; harden-

ing, 40; omission, 40.

word accent, $55 ; 62$ 


\section{LIST OF IRREGULAR VERSES}

in Vergil's Eneid, i-vi, which are discussed in the foregoing pages

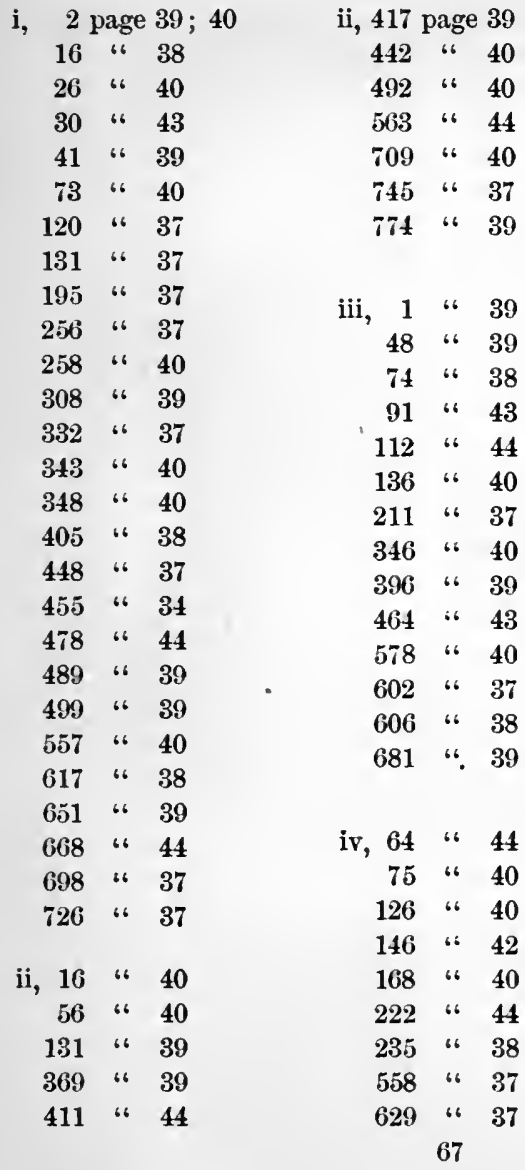

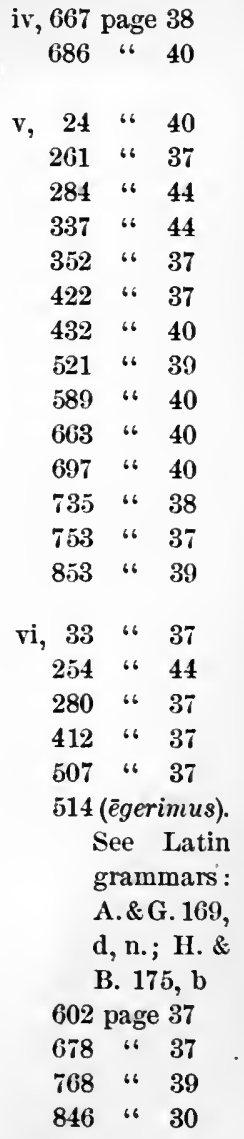



ANNOUNCEMENTS 



\section{I R G I L}

REVISED EDITION

Edited by JAMES B. GREENOUGH, late Professor of Latin in Harvard University, and GEORGE L. KITTREDGE, Professor of English in Harvard University, formerly Professor of Latin in Phillips Exeter Academy

AENEID, BOOKS I-VI, with a special Vocabulary. 12mo. Half morocco. $x l v+709$ pages. Illustrated. List price, \$1.50; mailing price, \$1.65.

AENEID, BOOKS I-VI, BUCOLICS, with a special Vocabulary. xlv +807 pages. Illustrated. List price, $\$ 1.60$; mailing price, $\$ 1.75$.

AENEID, BOOK I, with marked quantities. Text Edition. 12mo. Paper. 33 pages. Illustrated. List price and mailing price, 15 cents.

T $N$ this edition Virgil's "Aeneid" is treated more as a piece of inspiring literature than as so much Latin that must be perfunctorily studied. The Introduction discusses the Augustan Age, Virgil's life, his fame, and the manuscripts by means of which his writings have come down to us. The directions for translation and metrical reading are suggestive and adequate. The Notes contain frequent quotations from Chaucer, Shakespeare, Milton, Spenser, Pope, and other English authors who have drawn inspiration from the "Aeneid." The text is profusely illustrated.

This volume is regarded by critical and competent Latin teachers as the most attractive as well as the most scholarly edition of "Virgil" for secondary schools yet issued in this country.

\section{GREENOUGH'S VIRGIL}

Edited by Jambs B. Grannovgh, late Professor of Latin in Harvard University.

GEORGICS AND AENEID, BOOKS VII-XII. 12mo. Cloth. 333 pages. Illustrated. List price, \$1.12; mailing price, \$r.25.

\section{TEXT EDITIONS}

AENEID, BOOKS I-VI, AND BUCOLICS. 12mo. Paper. I8I pages. List price, 40 cents ; mailing price, 45 cents.

AENEID, BOOK VII-XII. I2mo. Cloth. 157 pages. List price, 35 cents ; mailing price, 40 cents.

COMPLETE TEXT OF VIRGIL, BUCOLICS, AENEID, AND GEORGICS. 12mo. Cloth. 228 pages. List price, 75 cents; mailing price, 85 cents.

\section{GINN \& COMPANY PUBlishers}




\section{ALLEN AND GREENOUGH'S \\ NEW LATIN GRAMMAR}

FOR HIGHER SCHOOLS AND COLLEGES

By J. B. Greenour, late Professor of Iatin in Harvard University ; George Lyman

Kittredgr, Professor of English in Harvard University; A. A. How ARD,

Professor of Latin in Harvard University; and BenJAM1N L. D'OogR, Professor of Latin in the Michigan State Normal College.

$12 \mathrm{mo}$. Half leather. 490 pages. List price, $\$ 1.20$; mailing price, $\$ 1.30$.

7 HIS well-known Latin grammar, although in a new form, still remains the Allen and Greenough Grammar in scope and general plan, and retains the characteristic qualities that have given the book a world-wide distinction. But the book has been revised in every detail to bring it into harmony with the latest results of scholarship the world over, and has been rearranged where necessary to make it as convenient for use as is possible.

The authors have been assisted on details by the most eminent specialists, among whom are Professor Sheldon of Harvard University and Professor Morris of Yale University. The book therefore is thoroughly trustworthy. All the most recent grammatical theories have been considered, and if they have not been adopted it is because the old ones are better. The paragraphs have been renumbered throughout, and the typography of the book has been completely changed. A new scheme of type display unquestionably marks the highest typographical achievement in books of this character.

\section{GINN \& COMPANY Publishers}


(1) 
University of Calliomia SOUTHERN REGIONAL LIBRARY FACILITY 405 Hilliard Avenue, Los Angeles, CA $80024-1383$ Return this material to the library from which it was borrowed. 


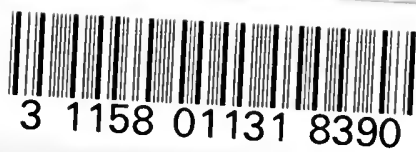

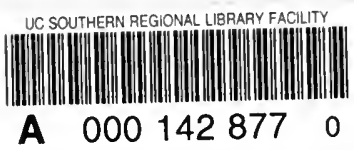


Unive Sol Li

ST 